\title{
Gene Expression Changes in Normal Hematopoietic Cells
}

\author{
Jack M. Lionberger ${ }^{1}$ \\ and \\ Derek L. Stirewalt ${ }^{2}$
}

${ }^{1}$ Dr. Jack M. Lionberger MD/PhD is an Acting Instructor at the Fred Hutchinson Cancer Research Center and the University of Washington. His research interests include hematopoietic stem cell biology and the influences of aging on stem cell dysfunction in the elderly.

Email: jlionber@fhcrc.org

${ }^{2}$ Dr. Derek L. Stirewalt MD is an Assistant Member at the Fred Hutchinson Cancer Research Center and Assistant Professor at the University of Washington Medical School. His research interests include the study of gene expression changes in normal and malignant hematopoietic cells and the development of high-throughput assays expression assays.

Email: $\underline{\text { dstirewa@fhcrc.org }}$

Derek L. Stirewalt, MD

Assistant Member

Genetics and Genomics

Clinical Division

D5-112, FHCRC

1100 Fairview Ave $\mathrm{N}$

Seattle, WA 98109

Office Phone: (206) 667-5386

Fax: (206)-667-6519 



\begin{abstract}
The complexity of the healthy hematopoietic system is immense, and as such, one must understand the biology driving normal hematopoietic expression profiles when designing experiments and interpreting expression data that involves normal cells. This chapter seeks to present an organized approach to the use and interpretation of gene profiling in normal hematopoiesis and broadly illustrates the challenges of selecting appropriate controls for high-throughput expression studies.
\end{abstract}

List of keywords: Hematopoiesis, microarrays, cDNA, transcriptome, proteome, cytokine, interleukin, malignancy, genome, epigenome, differentiation, polymorphism, aging, somatic mutation, pharmacogenetics, post-translational modification, stem cell.

\title{
INTRODUCTION
}

As discussed in other chapters, malignancies demonstrate significant "disease-specific" expression changes compared to normal hematopoiesis. However, these findings must be interpreted with caution and in full view of critical differences between normal and diseased cellular biology. ${ }^{1-3}$ Several fundamental issues (outlined below) must be addressed to effectively design experiments and to appropriately interpret results.

What are the characteristics of "normal" hematopoiesis? Hematopoietic cells must constantly recognize a wide variety of internal and external signals in order to maintain a balanced yet flexible blood system. Consequentially, normal hematopoietic cells will often display widely divergent transcription profiles depending upon their environmental cues and immediate surroundings. For example, a hematopoietic system undergoing the stress of an acute hemorrhage will present a markedly different molecular expression signature than one in homeostasis. ${ }^{4}$ Likewise, hematopoietic stem cells (HSCs) from a 65 year-old smoking male on multiple medications are likely very different from healthy newborn HSCs, despite a shared immunophenotype. ${ }^{5}$ Therefore, unrecognized biological variables within the subject may be responsible for expression changes that can be inappropriately ascribed to pathologic conditions. For this chapter, normal hematopoiesis will be defined as any non-malignant state. Although too broad for many comparisons, this definition highlights the absolute necessity to acknowledge and control for "normal" biological factors that may cause inter-individual variation in expression data.

A similar but distinct issue relates to the heterogeneity of cells within the hematopoietic system. What are the appropriate populations of cells for comparisons between normal and diseased states? The answer to this question will profoundly impact the biological and technical aspects of an experiment. To illustrate this point, consider that "normal" CD34+/CD38- and CD34+/38+ cells have overlapping yet unique expression signatures, ${ }^{6,7}$ and similar differentiation specific expression signatures have been found in leukemic blasts. ${ }^{8}$ Therefore, if one compares the expression profiles between relatively homogenous CD34-positive AML blasts and heterogeneous normal bone marrow samples, there will certainly be a large number of expression differences that initially appear to be associated 
with the disease phenotype. However, upon further investigation, it becomes clear that many of the "AML-specific" expression changes may be secondary to lineage-specific variations in the trascriptome. ${ }^{3}$ To further complicate matters, many hematopoietic malignancies inappropriately express a variety of differentiation markers, making precise determination of the optimal comparison population a challenge. $^{9}$ Due to the lack of an absolutely correct choice, the appropriate control will depend on the intellectual bias, available resources, and specific goals of the investigator.

How do investigators inadvertently change the biology of cells? Cells require extensive handling prior to most expression profiling studies, and many times, the normal and diseased populations undergo different processing. For example, leukemic samples obtained from large cooperative groups are frequently shipped from outside institutions, resulting in a delay of processing, while normal samples are often obtained and processed locally. In many cases, studies use frozen samples, introducing another potential variable that can impact expression. ${ }^{3}$ Processing, thawing, and other typical laboratory manipulations impact the biology and expression profiles of normal and abnormal cells. ${ }^{10}$ Together, these factors may introduce uncontrolled or unknown methodologic biases that can lead to erroneous findings and decrease the experimental power to detect true biological differences.

A firm grasp of the biology governing normal hematopoiesis is essential to the study of the molecular aspects of hematopoietic diseases. This chapter focuses on expression profiles of normal cells and factors that alter expression in these cells. It is intended to provide a framework to facilitate the reader's evaluation of studies that focus on gene profiles of normal hematopoietic cells, or use them as a point of comparison. In general, the term "expression" will refer to either mRNA or protein expression in order to illustrate the concept in its broadest sense. When appropriate, the authors will clarify the type of expression by specifically referring to either mRNA or protein expression. Obviously, a comprehensive review of any specific topic regarding the transcriptome, its regulation, or translated products is beyond the scope this chapter. Additional concepts and details are available in the cited references and reviews.

\section{Chapter Goals:}

- Outline the current understanding of gene expression in normal hematopoietic cells.

- Provide a basic understanding of the factors that govern the normal hematopoietic transcriptome.

- Explore the impact of intra-individual, inter-individual and environmental factors on gene expression.

- Discuss the pitfalls of current approaches examining normal hematopoietic gene expression.

FIGURE 1 TO BE INSERTED HERE.

\section{FACTORS INFLUENCING EXPRESSION IN NORMAL HEMATOPOIETIC CELLS}


Intrinsic and extrinsic factors that control and alter expression profiles are broadly considered in this section, starting with the genome and working outward to the environment (Figure 2). It is incorrect to derive from this structured description that the regulators of expression function independently of one another, and in fact, considerable cross-talk and coordination occurs between them.

\section{FIGURE 2 TO BE INSERTED HERE}

\section{Impact of Genomic Changes on Expression}

For years, investigators have been aware of genetic divergence across populations and among family members, which is demonstrated by inter-individual differences in behavioral and physical attributes. Historically, the genome was modeled as rigidly static after conception, and monozygotic twins were expected to share an exact genetic unity. This assumption has recently been shattered by studies using high resolution genomic arrays. ${ }^{11,12}$ Unexpected levels of copy number variation (CNV) between monozygotic twins provide support for a model of sub-chromosomal genetic divergence after the splitting of the embryo, indicating that the normal genome may be more dynamic than once appreciated. ${ }^{13}$ An even more dramatic example of post-conception genomic divergence has recently been described in mammals. Microsatellite mutations in mice occur with sufficient frequency during early organogenesis that the genetic variability can be used to model the developmental relationship of different tissues within the animal. ${ }^{14}$

To further complicate matters, an individual's genome continues to change ex utero, probably as a result of the intrinsic aging processes and environmental factors. ${ }^{15}$ For example, non-allelic homologous recombination naturally increases as a function of normal aging in humans, and studies reveal increased DNA damage in the hematopoietic cells from older animals in the absence of malignant disease. $^{16,17}$ If these genetic changes affect critical regulatory sequences within the gene, then transcription, translation, and post-translational modifications could be altered and result in a modified phenotype. The effect or significance of incidental age-related acquired genomic variation on gene expression is unclear; however, there is an effort to better describe the degree of genetic variation in humans and identify the factors that cause genetic changes within normal cells. ${ }^{18}$ Until we have a better understanding of the mechanisms governing genetic variation across individuals and acquired genetic alterations within individuals, studies comparing normal and diseased states must be interpreted cautiously. A real possibility exists to misinterpret genetic "lesions" or expression changes in the diseased population that actually represent normal divergence. ${ }^{13}$

\section{Epigenetic Regulation of Expression}

Epigenetic factors regulate gene expression. ${ }^{19,20}$ For example, methylation of cytosines modulates transcription factor binding at critical promoter sequences of some genes, thereby altering expression. ${ }^{5,20}$ As with the genomic variability discussed above, methylation states are dynamic. ${ }^{21}$ Genes that govern methylation indirectly control the expression of an even larger number of genes. ${ }^{22}$ Regulators of methylation vary with the cell cycle, overall health of the cell, and differentiation stage. ${ }^{5,21}$ In addition, external exposures (e.g., stroma), molecules (e.g., folate), environmental factors (e.g., 
radiation and tobacco smoke), and drugs (e.g., 5-azacytidine) impact the methylation states in hematopoietic cells, providing another level of transcriptome modification and regulation. ${ }^{5,20}$

Chromatin scaffolding houses the genome and is an epigenetic regulator of transcription. ${ }^{20,23}$ Chromatin is composed of proteins, primarily histones, which actively organize the genome, engaging and regulating transcriptional machinery. ${ }^{24,25}$ A variety of genes, conditions, and mechanisms dictate the dynamic and plastic nature of chromatin structure. ${ }^{26}$ For example, histone acetylation/deacetylation plays a critical role in modifying chromatin configuration and impacts transcription. ${ }^{27}$

\section{Role of Transcription Factors in Gene Expression}

Nuclear proteins bind to transcription factor binding sites (TFBS) that lie within promoter regions and initiate synthesis of RNA. ${ }^{28}$ There are probably 100 s - 1000s of transcription factors expressed at any one time in normal and malignant cells, and transcription factor may have thousands of binding sites and control hundreds of genes. ${ }^{28}$ For example, TP53 (a tumor suppressor gene and transcription factor) binds to over 500 loci, $^{29}$ while MYC may have 10,000 - 20,000 unique TFBS within the genome. ${ }^{30}$ Furthermore, transcription factors can have multiple isoforms that have different affinities to the TFBS and produce opposing biological effects. ${ }^{31}$

Numerous context-dependent genetic and epigenetic components influence the function of a transcription factors. The complexity of the system is challenging to model because transcription factors can be directly involved in expression of genes at multiple levels. For example, IKAROS family zinc finger 1 (IKZF1) promotes transcription, recruitment and modification of other transcription factors, and influences chromatin remodeling. ${ }^{32}$ The interactions between the genome, primary sequence methylation, chromatin structure, and thousands of transcription factors set the stage for a versatile and adaptable transcriptome, which is capable of simultaneously maintaining homeostasis yet has the capacity to rapidly respond in times of stress.

\section{The Changing Transcriptome}

There are numerous components to the transcriptome: messenger (m)RNA, ribosomal ( $r$ )RNA, transfer ( $\mathrm{t}$ )RNA, and the recently described non-coding (nc)RNA, ${ }^{33,34}$ and each of these components play a critical role in regulating protein expression. mRNA transcripts are perhaps the most studied of all the different transcriptional components. After transcription, pre-mRNA products undergo posttranscriptional modifications and are eventually processed into mature mRNA transcripts. These mature mRNA transcripts form the template for translation and thus, directly regulate protein expression. Due to their pivotal role in regulating this expression, the levels of mRNAs are tightly regulated via timely expression, maintenance, and degradation. The inherent instability of mRNA can work against accurate assessment of transcript levels, introducing a potential experimental pitfall that may be difficult to control for on a gene by gene basis.

For many years the biological activity of ncRNAs was unrecognized, and they were thought to arise from non-specific transcriptional activity or as the by-product of normal RNA processing. Interest in ncRNAs increased in the mid-late 1990s when it became clearly apparent that ncRNAs are highly 
conserved across species and that some ncRNAs have functional activity. ${ }^{33}$ Functional experiments demonstrated that these simple but eloquent gene products (i.e. microRNAs, or miRNA) provide a versatile method for controlling expression by binding and modulating the stability of mRNA and/or its translation. $^{35-38}$ The expression of many miRNAs (e.g., miR-181) fluxuate during hematopoiesis, consistent with recent studies demonstrating a critical role for these transcripts in normal differentiation programs. $^{35,36,39}$ Other ncRNAs may serve as a physical linkers between RNA-binding proteins (e.g., translocation in liposarcoma, TLS) and DNA promoter sequences. In this model, the ncRNAs cause an allosteric change within the RNA-binding protein, which, in turn, promotes the association of other transcriptional proteins and represses promoter activity. ${ }^{40}$ Although ncRNAs are sometimes expressed at very low levels, they may still have profound biological effects. Additionally, recent data suggest that ncRNA species have greater variety than the mRNA transcripts in the cell, although further characterization is required. ${ }^{34}$ Even if only half of the projected ncRNAs are functional, they add yet another level of complexity to the biological equation that has not been encountered since the discovery of the genome.

\section{The Vast and Varied Proteome}

Analogous to the transcriptome, the proteome is the sum of all translation products, and is the point at which genetic changes become relevant to the biology of the cell. Proteins are responsible for adaptation, metabolism, and survival. The modern biologist must model real-time non-linear behavior of subcellular signal transduction pathways, microcompartments, and organelles that have critical spaciotemporal associations with diverse cellular apparatuses, ion gradients, cytoskeletons, carbohydrates, etc. Compared to the leviathan effort needed to sequence the human genome, the work required to comprehensively model the proteome is vastly greater because not all protein characteristics are encoded by genomic elements. Post-translational modifications (PTMs) can activate, modulate, and/or terminate the function of a protein, while the intracellular context of a protein can profoundly alter the cell phenotype. ${ }^{41,42}$ The four-dimensional model of the biology mediated by proteins is described by the field of proteomics with subclassifications of data referred to by novel terms including the "interactome" ${ }^{43}$ or the "metabalome," concept of carbohydrate modification of proteins called the "glycome." ${ }^{46}$ Experimental approaches to these diverse fields require specialized techniques and software that are beyond the scope of this chapter, and the reader is referred to the many excellent reviews for additional information.

A common application of proteomics is the screening of candidate pharmacologic molecules prior to animal studies. ${ }^{47}$ Thousands of potential agents can be screened for specific interactions with key biologically active proteins. Candidate molecules that pass the first in vitro tests move forward to the next round, while molecules with presumed deleterious effects, demonstrated by specific affinities, are eliminated. If the underlying interaction is misunderstood, potentially beneficial may be overlooked and potentially dangerous compounds may be inappropriately advanced. There is optimism about using a similar in vitro approach to predict a patient's response to therapy in a burgeoning discipline of pharmacogenomics. $^{48}$ 
The field of proteomics is in its infancy, but has already demonstrated utility. Nevertheless, current challenges include isolation of specific cell sources and managing the vast amount of information generated. An additional critical component is the need to define appropriate thresholds to delineate the biological relevance of a protein-protein interaction. This challenging issue may vary for each target because protein interactions are not binary, and both non-specific and low-affinity binding can be biologically significant.

\section{Regulation of Expression via Cell Membrane Proteins}

Communication between hematopoietic cells and the microenvironment occurs through receptors embedded in the plasma membrane. These receptors may function to anchor the cell to a niche $e^{49-52}$ and often provide critical points of contact for internal cytoplasmic stuctures. ${ }^{53,54}$ Receptors are pivotal to the biology of the cell and often define a cell's identity, differentiation stage, and disease state (i.e., "normal" vs. "abnormal"). 9,55 Membrane-associated receptors and integrins are numerous, and their role in hematopoiesis is a field of investigation under constant flux that has regularly been reviewed in detail. ${ }^{51,56-70}$ We will briefly highlight major points of interest for several of the most studied receptors below and in Table 1.

Receptor tyrosine kinases (RTKs) and cytokine receptors (CKRs) are classes of proteins that play critical roles in hematopoietic biology and are expressed on normal hematopoietic cells (Table 1). RTKs contain intrinsic kinases that drive intracellular signaling activity and are divided into more than 20 subclasses. $^{71}$ The RTK subclass III (the PDGFR family) is the best-studied in normal and abnormal hematopoiesis, and is composed of 5 homologous members (CSF1R, FLT3, KIT, PDGFRA, and PDGFRB). ${ }^{71-}$ 73 The shared structure includes: five extracellular immunoglobulin-like domains (EMD), a transmembrane domain (TMD), juxtamembrane domain (JMD), two intracellular tyrosine kinase domains (TKD), and a hydrophilic insertion/linker domain between the TKDs (KID). ${ }^{72,73}$ Compared to RTKs, CKRs do not have intrinsic tyrosine kinase activity and must recruit kinases to initiate intracellular signaling. Two classical examples of hematopoietic CKRs include CSF2R (GM-CSF receptor) and CSF3R (G-CSF receptor). ${ }^{59}$ At the plasma membrane, the extracellular domains of RTKs and CKRs bind specific cytokines or growth factors (Table 1). ${ }^{72}$ Ligand binding induces conformational changes that in turn either activate intrinsic kinase activity (RTK only) or recruit cytoplasmic kinases to initiate diverse signal transduction pathways. Therefore, the membrane receptor expression pattern of a specific cell dictates ligand binding and, ultimately, defines the cell responses to the repertoire of ligands in its environment.

The Notch and WNT families of receptors initiate intracellular signals that have been increasingly implicated in normal and abnormal hematopoiesis. Notch signaling plays an active role in tissue homeostasis, with initially studies first describing its role in embryonic development. ${ }^{65,74,75}$ In humans, Delta-like and/or Jagged ligands bind to four Notch receptors, and studies suggest that Notch activation may to play some role in HSCs maintenance and/or expansion. ${ }^{51,65}$ In fact, recent work has found that Notch activation can be utilized to expand primitive HSCs for transplantation. ${ }^{76}$ However, it remains unclear if Notch is required for perpetual maintenance of these cells. ${ }^{65,74,75}$ WNT signaling may also play some role in promoting the expansion of primitive HSCs and has been implicated in HSCs selfrenewal. ${ }^{75}$ Although Notch and WNT pathways represent the "state-of-the-art" in our understanding of 
how membrane receptors influence hematopoiesis, many aspects of these receptors' biology remains unknown, highlighting the need for additional studies.

\section{TABLE 1 TO BE INSERTED HERE}

\section{METHODS TO EXAMINE THE REGULATORS OF EXPRESSION AND EXPRESSION}

Since the completion of the human genome project, there has been an explosion of novel platforms to examine genomic, epigenetic, and expression changes in hematopoietic cells (Table 2). Current genomic technologies have the capacity to examine millions of single nucleotide polymorphisms (SNPs) and acquired mutations using relatively little starting material, ${ }^{77,78}$ and these assays have already been found to be extremely useful for identifying nucleotide changes, uniparental disomy (UDP), and loss of heterogeneity (LOH) in both normal and diseased states. ${ }^{79}$ As this technology evolves, arraybased SNP and comparative genomic hybridization platforms will enable researcher to study the genetic variability in hematopoietic cells with increasing precision and genomic coverage. Recently, highthroughput full genome sequencing (FGS), or whole genome sequencing (WGS), has become a reality, with novel pyrosequencing technologies able to sequence $>400-600$ Megabases in 10 hours. ${ }^{80}$ Using this technology, investigators have sequenced the entire genome for selected subsets of human cells, including malignant blasts from an AML patient with normal cytogenetics. ${ }^{81,82}$ These cutting edge technologies have rapidly advanced our understanding of how genomic changes impact expression, identifying thousands of new polymorphisms and promoter loci. ${ }^{78,83,84}$

Currently, there are a number of different techniques to examine DNA methylation and histone marks - two major epigenetic mechanisms for controlling transcription. DNA methylation changes were first examined using restriction enzyme digest/PCR assays. The key to this approach is the use of "methylation specific" restriction enzymes that cleave unmethylated alleles but fail to digest methylated alleles. ${ }^{85}$ Gene-specific PCR primers can be developed that flank the digestion site and amplify only the protected, methylated DNA sequences. Using this method, investigators first demonstrated that the GSCF promoter displays different methylation states in granulocytes (hypomethylated, expressed) and lymphocytes (hypermethylated, not expressed). ${ }^{86}$ One major limitation of this technique is that only sequences with a methylation-specific restriction enzyme sites can be assessed. The discovery that bisulfite treatment of DNA converts unmethylated cytosines to uracil provided a major advancement in the development of more comprehensive, high-throughput techniques to examine global DNA methylation patterns. ${ }^{87}$ By changing the DNA sequence, investigators were able to design primers or hybridization probes that differentially target non-modified (methylated) and modified (unmethylated) sequences, leading to the development of global methylation arrays. ${ }^{87-89}$ Currently, there are a number of techniques that can be used to examine the relationship of chromatin structure and genes, but the workhorse of these investigations is the chromatin immunoprecipitation (CHiP) assay. ${ }^{90}$ With CHiP assays, chromatin is precipitated with an antibody, and the pellet is interrogated by a variety of methods, including PCR of specific genomic fragments of interest, and as with methylation arrays, high 
throughput $\mathrm{CHiP}$ arrays are becoming increasingly more comprehensive and popular in the research community. ${ }^{91}$ Together, these novel techniques provide a powerful set of tools to characterize the multitude of epigenetic changes in hematopoietic cells.

High-throughput technology for examining mRNA, or total RNA, expression has been in use for over a decade. ${ }^{92,93}$ The first arrays examined expression of a limited number of genes, using relatively simple platforms, but the technology quickly proved to be a powerful tool of characterizing diseases and interrogating the molecular biology of cells. ${ }^{94}$ With refinements in RNA array technology, there has been a dramatic increase in the number of targets that can be evaluated - with the current arrays displaying the capacity to examine more than 45,000 transcripts and 35,000 unique genes. ${ }^{95}$ As the importance of non-coding RNAs (discussed elsewhere in this and other chapters) became known, ${ }^{36,38}$ arrays were developed to specifically examine transcription of miRNAs. ${ }^{96}$ Investigators have also adapted the high-throughput "deep sequencing" techniques used in FGS to the transcriptome, identifying novel isoforms and alternative splice variants, suggesting that $92 \%$ of genes may undergo alternative splicing. ${ }^{82}$ Capitalizing on these data, more sophisticated microarrays are being developed that will allow researchers to discriminate between isoforms and quantify alternative splicing. ${ }^{97,98}$

At the level of the proteome, the most basic question is whether or not a protein is present within a cell or in a comparison of cell lysates. Two-dimensional protein electrophoresis (2DPE), based on separation of proteins first by isoelectic point and then by denaturation electrophoresis, provided the first insight into differential protein expression in a holistic fashion. ${ }^{99}$ Antibodies remain the most typical approach for specific identification of proteins and are used in a variety of applications, including ELISA assays, western blotting, affinity chromatography, and immunoprecipitation. Some antibodies have been raised to specific activation or phosphorylation states of proteins, allowing a modicum of functional data. ${ }^{100}$ However, mass spectrometry (MS) does not necessarily require specific antibodies to identify proteins or peptides; rather MS relies upon ionization of peptides into charged particles that can be characterized after passing them through electric or magnetic fields. ${ }^{101,102}$ Another major strength of MS is the ability to detect PTMs on peptide fragments, and the technique is versatile enough to use many sources of materials. ${ }^{103,104}$ Thus, MS has been increasingly adapted to provide specific protein identification and high throughput analyses of the proteome. ${ }^{104}$ However, maintaining a system to simultaneously investigate the biological context of a range of protein interactions during manipulation will require creative approaches and sophisticated experimental design. ${ }^{102,103}$ Examples of the tools used to evaluate the proteome are listed in Table 2, but experimental approaches to interrogating the proteome are diverse and manifold.

Although these techniques may hold the key to unlocking the biological mysteries of normal and abnormal hematopoietic cells, high-throughput platforms have significant limitations. Importantly, they can only provide "snapshots" of the genetic, epigenetic, and expression changes that occur over time. Therefore, momentary events (cell processing, target isolation and enzyme efficiencies) directly impact the cells and the data. ${ }^{3,10}$ Consequentially, quality controls are essential for proper analyses and interpretation of the results. In addition, most of these platforms have a finite number of potential targets that can be examined, potentially missing critical genetic, epigenetic, and/or expression changes. Finally, the amount of data generated can be daunting, pushing the limits of current computing 
technology and creating a need for special statistical methods of normalizing, analyzing, and interpreting the data. ${ }^{105,106}$

\section{TABLE 2 TO BE INSERTED HERE}

\section{DIFFERENTIATION PROGRAMS AND THE TRANSCRIPTOME}

The hematopoietic system is amazing in its complexity, flexibility, precision, and capacity. Aging alone does not exhaust the normal hematopoietic system, nor does recurring hemorrhage or chronic and repetitive infections. In addition, under normal circumstances all terminal cellular lineages are precisely maintained without excess. This is particularly impressive because the disparate internal and external regulation within each compartment independently act on a shared population of primordial cells. The activities of the hematopoietic system can be artificially separated into different functions: i) maintenance of the stem cell pool; ii) cell fate/lineage decision making; iii) expansion of daughter cells; and iv) feedback regulation from the terminal functional cells. Collectively, these and other tasks are highly regulated by expression changes within the cells to secure maintenance of the hematopoietic system and dictate differentiation of hematopoietic cells. Examples of differentiation regulation that broadly illustrate these complex mechanisms follow below, starting at global transcriptional assessment of HSCs and proceeding to specific examples of expression changes that control differentiation.

One of the greatest challenges in the study of the normal hematopoietic system is characterization of the pluripotent stem cell. This cell compartment has two mutually exclusive roles: either to commit to proliferation and generate functional circulating cells, or to maintain "stem-ness" as an undifferentiated normal stem cell. ${ }^{107,108}$ The cells that make this decision are exceedingly rare, currently do not have an absolute marker of identity, and therefore, can only truly be identified by transplantation experiments demonstrating successful engraftment of enriched cell populations. ${ }^{109}$ Clonal stem cell experiments are possible in mice, but even in this system approaches are limited to evaluation of mature stem cell progeny and retrospective extrapolation. An ideal experiment to define the expression changes associated with critical HSC decisions would involve sequential array assessment of a pure population of HSCs over time and as the cells respond to specific ligand challenges.

By comparing neuronal, hematopoietic and embryonic stem cell transcriptomes, investigators have identified a cadre of transcripts common to maintaining "stem-ness", as well as expression signatures of individual stem cell groups. ${ }^{110,111}$ The Ivanova group further subdivided populations into Long Term HSC (LT-HSC), Short Term HSC (ST-HCS), Lineage Committed Progenitors (LCP), and mature blood cells. Each of these hematopoietic subpopulations had an overrepresentation of specific signaling ligands, receptors, and adhesion molecules. The most primitive LT-HSC notably expressed several critical genes Wnt10A, Erg, Hegfl, Bmp8a, and Agpt, many of which had previously been recognized as playing a critical role in maintenance or proliferation of the primitive HSC compartment. ${ }^{110}$ In addition, the studies found that primitive HSCs may simultaneously express ligand/receptor pairs (e.g., Wnt10A/Frizzled and Agpt/Tek), suggesting autonomous regulation of some signaling pathways may be occurring in HSCs. ${ }^{110}$ The same studies found that the HOX family displayed differential expression patterns among the subpopulations. For example, Hoxa5 and Hoxa10, both of which disrupt 
differentiation, were expressed primarily in cells retaining stem-ness (LT-HSC), while Hoxb4 and Hoxa9, both of which are associated with the cell expansion, were expressed in more differentiated, proliferative populations. ${ }^{110}$ However, when data from the two above-mentioned publications were compared by a third party, the degree of concordance between the studies regarding the transcripts common to stem cells was low. ${ }^{112,113}$ The published exchange of opinions on this data (the primary papers, the counter analysis, and the rebuttal) are well worth reading as a primer regarding the complex issues involved in expression profiling and the application of this technology to rare cells. ${ }^{112-114}$

Other investigators have returned to similar target populations as isolation techniques, definitions of cell populations, and microarrays have improved. Using improved arrays, Fosberg et al. confirmed some of the LT-HSC transcriptome elements of previous authors (e.g.,ROBO4 and Slit-like2 ligand receptor pair) and the general trend of the preservation of "stem-ness" genes in earlier cells (Hoxa5 and Hoxb5), with proliferation genes arising in more mature forms (Hoxa9). ${ }^{115}$ However, intriguing new elements were also described (e.g., previously undescribed adherens junctional complex proteins, like Esam1), suggesting novel elements of HSC biology. ${ }^{115}$

Array RNA data and the transcriptome only tell the beginning of the story. Translated proteins are responsible for much of the functional biology governing differentiation, and these regulatory proteins may have unique and overlapping functions. For example, CRE binding protein (CBP) and p300 have a significant amount of structural homology, and both proteins play very active roles in chromatin remodeling, suggesting a potential functional redundancy. ${ }^{116,117}$ In fact, CBP and p300 proteins both harbor the "KIX" domain, which is a binding site for the transcriptional factors CREB and c-myb. However, site-directed mutagenesis studies reveal that mutations in the KIX domain of the two genes produced distinct functional responses. Mice with a CBP-KIX mutation displayed no significant alterations in hematopoiesis, while the mice harboring the same KIX mutation in p300 had multilineage abnormalities. ${ }^{118}$ This study stands in contrast to the effect seen by a frank single knockout of each gene, in which a more dramatic disruption of hematopoiesis was seen in the CBP knockout. ${ }^{119}$ Certainly, experimental technique variation, specificity of the mutants, and/or the mouse strains in each experiment may have a role in the discordant results; alternatively, each protein may have a distinct function in HSC biology that will be elucidated with further investigation. Consistent with this assertion is the data provided by a third study, which found distinct roles for the two proteins, with CBP influencing HSC renewal and p300 influencing differentiation. ${ }^{120}$ Interestingly, when the p300 doubleknockout HSCs were transplanted into WT animals, the differentiation defect was overcome, suggesting the intriguing possibility that the p300-deficient phenotype is influenced by the stroma rather than a HSC autonomous mechanism. ${ }^{120}$ Given the wide range of roles that CBP and p300 play in the cell, it is perhaps not surprising that distinct facets of their biological roles are evident in different experimental systems. This example underscores the complexity of the functional response of even relatively homologous proteins and how subtle changes in the environment may dramatically change impact their effect.

As a cell moves through differentiation, innate programs are activated within cells at immature stages maintain lineage commitment via positive and negative feedback loops. Transcriptional factor upregulation can serve as the key to making cell fate decisions, and may act via repressor mechanisms 
to maintain the decision. For example, GATA-1 and PU.1 are expressed and promote differentiation in the erythroid and megakaryocytic lineages, respectively. Furthermore, each protein drives a positive feedback loop for its own expression, and a negative feedback loop for the expression of the other transcription factor. ${ }^{121,122}$ These types of complex and tightly regulated programs help to prevent inappropriate expression of genes at the wrong stage of differentiation.

As previously described ligands and their receptors orchestrate a complex symphony of selfrenewal, proliferation, and differentiation during hematopoiesis (Table 1). Cells express a unique set of receptors and ligands at specific points of in the differentiation process, at times forming auto/paracrine feedback loops. A recent study carefully evaluated the FLT3/FLT3LG system in CD34+ cells, an important pathway in undifferentiated hematopoietic cells, and showed that FLT3 receptor and ligand were both produced. Additionally, the a FLT3 receptor inhibitor (lesaurtinib) promoted upregulation of both the ligand and receptor, suggesting autonomous regulation. ${ }^{123}$ In another microarray based study, human CD34+ cells expressed multiple different cytokines (e.g., VEGF, HGF, IGF1, IL16, TGFB1, and TPO). ${ }^{124}$ This study correlated mRNA expression with protein production and biological function, and addressed some of the potential difficulties in modeling gene profiling assessment in the form of microarrays. ${ }^{125}$

\section{EFFECTS OF AGING ON HEMATOPOIETIC EXPRESSION}

The hematopoietic system undergoes a number of significant functional and anatomic changes with age. Overall, there is a diminution of the immune and growth factor responsiveness. ${ }^{126-130}$ Furthermore, the incidence of most hematopoietic diseases (e.g., anemia, malignancies) dramatically increases with age. ${ }^{131}$ Currently, it is unclear exactly what biological factors are responsible for the agerelated changes in the hematopoietic system. Genetic and epigenetic changes within hematopoietic progenitor/stem cells (HPCs/HSCs) and their progeny definitely increase over the life of an organism. ${ }^{108}$ For example, HSCs from older mice display a marked reduction in their capacity to repair DNA damage, and this deficiency leads to decreased self-renewal, increased apoptosis, diminished capacity to maintain normal hematopoiesis, and "functional exhaustion". ${ }^{16,132}$ Despite these findings (or perhaps due to this dysfunction) older mice have an increased number of HSCs, although these cells demonstrate reduced repopulating potential and a propensity towards myeloid skewing. ${ }^{108,133-135}$ Together, these findings strongly support the conclusion that aging expands one or more pools of dysfunctional HPCs/HSCs that limit the hematopoietic system response, especially in times of stress. Since DNA repair processes are disrupted with aging, DNA damage accumulates in the cells of older adults. Like many other cancers, multiple genetic, epigenetic, and/or transcriptional events are required to transform normal hematopoietic progenitor/stem cells. ${ }^{136-139}$ Therefore, dysfunctional HPCs/HSCs may acquire the necessary and sufficient transforming events over time, leading to the development of hematopoietic malignancies and explaining the increased incidence of hematopoietic malignancies in older adults. ${ }^{16}$ If so, the characterization of the nature and identity of ARECs may provide insight into the biology of normal aging and the development of age-associated diseases such as cancer.

Both genetic and epigenetic mechanisms are involved in generating specific age-related expression changes (ARECS) in hematopoietic cells. Werner syndrome is an extensively studied premature aging disorder that is caused by a specific mutation in the WRN gene. ${ }^{140,141}$ The WRN protein 
functions as a DNA helicase and exonuclease, aiding normal recombination and repair. ${ }^{142}$ The common WRN mutations result in a truncated protein that lacks appropriate and necessary nuclear localization, ${ }^{143}$ and the subsequent decrease of WRN activity leads to the accumulation of genetic damage, genetic instability, premature aging, and cancer. ${ }^{142}$ It is unclear whether the decrease in WRN expression and/or its activity plays a role in "normal" hematopoietic aging; however, expression profiles in fibroblasts of Werner syndrome patients and older adults reveal a set of common ARECs as compared to young healthy controls. ${ }^{144}$ In addition, WRN activity is lost in a number of age-related diseases, including several malignancies. ${ }^{145,146}$ Taken together, these data suggest that Werner syndrome may be a reasonable model for "normal" aging and the development of age-related disease. ${ }^{144}$

Some ARECS may directly facilitate the transformation process (T-ARECs). We recently examined the ARECs in human and murine HPCS/HSCs and found that interferon regulatory factor 8 (IRF8) displayed robust ARECs with in human CD34+ cells, murine long-term repopulating HSCs (LTRHSCs), and human T-cells. ${ }^{147}$ In all three hematopoietic cell types, IRF8 expression decreased with aging. Previously, IRF8 insufficiency has been associated with the development of hematopoietic malignancies in murine models, ${ }^{148,149}$ and many human hematopoietic malignancies (AML, CML, MDS) display decreased IRF8 expression. ${ }^{150-152}$ These results suggest that IRF8 insufficiency with aging may facilitate transformation, but additional studies will be required to confirm these results and to identify potential other T-ARECs, if they exist.

In an interesting twist, some ARECs appear to play a role preventing the development of agerelated diseases such as cancer. For example, cyclin-dependent kinase inhibitor 2A (CDKN2A, a.k.a., $\mathrm{p} 16^{\text {INK4a }}$ ) is a tumor suppressor gene that regulates the cell cycle, ${ }^{153}$ and loss of CDKN2A function is associated with hematopoietic malignancies, most notably acute lymphoblastic leukemia. ${ }^{154,155}$ However, numerous studies have found that CDKN2A expression increases in an age-dependent manner in most tissues, including the hematopoietic system. ${ }^{133,156,157}$ TP53, another tumor suppressor gene, also displays a similar paradoxical expression pattern in aging and malignant transformation. Like CDKN2A, loss of TP53 activity promotes the development of hematopoietic malignancies, ${ }^{158-161}$ and in mice, a "hyperactive" TP53 phenotype has been found to protect against cancer development. However, these same mice displayed a $20 \%$ reduction in life-span as compared to their TP53 wild-type counterparts, and in fact, the TP53 hyperactive mice prematurely develop classic signs of aging (e.g., osteoporosis and tissue atrophy). ${ }^{162}$ Furthermore, genetic polymorphisms in TP53 that modulate its expression have been found to be associated with age-related conditions and altered human survival curves. ${ }^{163,164}$ For example, subjects with the TP53 ${ }^{72-\text { Pro/Pro }}$ genotype (associated with a reduced TP53 apoptotic potential and activity) have an increased risk of cancer ( 2.54 fold, $P=0.007$ ), but they also have a $41 \%$ increased overall survival $(P=0.032)$ when compared to TP53 ${ }^{72-A r g / A r g}$ carriers. ${ }^{164}$ These controversial results suggest that increased TP53 activity may protect against cancer at a cost of longevity. A more recent study found the apparent TP5 $3^{72-\text { Pro/Pro }}$ benefit may be more related to improvements in survival after the diagnosis of life-threatening diseases than an actual decrease in the "aging" process per se. ${ }^{108,163,165,166}$ Taken together, these and other studies suggest a delicate, evolving balance between the need for cell survival and an increased susceptibility for transformation as we age. In this model, DNA damage promotes "protective" ARECs (P-ARECs) that induce DNA repair and/or apoptosis, preventing 
transformation. Unfortunately, this protection comes at a price, namely, an age-related decline in the ability to replenish the tissues and cellular exhaustion of organ systems. If P-ARECs are lost due to genetic or epigenetic events, aging cells may more readily acquire necessary and sufficient transforming hits that lead to development of malignant clones (Figure 3).

New advancements in microarray design and labeling techniques have reduced the quantity of starting material necessary to detect ARECs. Most investigations have examined either nonhematopoietic tissue (e.g., fibroblasts, muscle, brain) or murine-derived hematopoietic cells. Chambers et al. identified approximately 3100 ARECs in murine HSCs. These investigators found an age-dependent down-regulation of genes involved in chromatin remodeling and maintenance of genomic integrity, while there was a concomitant increase in the expression of genes associated with stress responses, inflammation, and protein aggregation. ${ }^{135}$ Rossi et al. examined a slightly less differentiated population of murine LTR-HSCs, and this study found marked ARECs for genes associated with myeloid development, which may provide some insight into the age-associated myeloid skewing. ${ }^{167}$ Furthermore, older LTR-HSCs also displayed increased expression of some genes that have previously been recognized as being involved in leukemic transformation. ${ }^{167}$ Due to the limited capacity to obtain highly purified populations of human HSCs, there have been relatively few studies examining ARECs in human hematopoietic progenitor cells. We recently found a number of genes with ARECs in human CD34+ and CD34+/38- cells, some of which also displayed similar ARECs in murine HSCs from other studies. ${ }^{147}$ Prall et al. has also examined ARECs in a limited number of human CD34+ cells. ${ }^{168}$ These studies identified three genes with major ARECs: KU-antigen 70 kD (KU70), microsomal glutathione Stransferase 1 (MGST1), and BCL2-interacting killer (BIK). ${ }^{168}$ The relatively small numbers of samples used in each of these studies limit the power to identify significant ARECs and assess potential interindividual variations in expression. Additionally, even the most highly purified populations of cells are probably composed of relatively heterogeneous subpopulations. Thus, many apparent ARECs may merely reflect the inability to select and examine truly identical cell populations in young and older adults.

\section{FACTORS IMPACTING HEMATOPOIETIC EXPRESSION}

Hematopoietic cells are constantly receiving, sending, and managing signals that are integral to the control of normal hematopoiesis. Key issues assigned to the hematopoietic microenvironment (i.e. "niche") are the maintenance and protection of the HSC pool, regulation of mitogenic signals, and oversight of appropriate differentiation. The importance of the microenvironment is illustrated in the case of an ablative transplantation. Immediately after transplantation, HSCs rapidly "home" to the appropriate hematopoietic niches within the bone marrow microenvironment. ${ }^{169}$ There are numerous factors that contribute to the homing nature of HSCs, some of which are cell-dependent, while others are microenvironment-dependent. For example, primitive hematopoietic progenitors express calciumsensing receptor ( $\mathrm{CaR}$ ) molecules. These CaRs detect and act upon subtle differences in calcium gradients and control the homing of HSCs to the appropriate stem cell niches. ${ }^{170}$

At a macroscopic level, the hematopoietic system must respond to environmental stressors such as radiation, toxins (tobacco), medications, and industrial exposures, and these environmental factors 
directly impact the expression profile of normal hematopoietic cells. ${ }^{5}$ Radiation exposure is one of the most extensively studied environmental exposures. Numerous studies indicate that even low doses of radiation promote expression changes in normal hematopoietic cells. ${ }^{171-175}$ Many radiation-induced expression changes involve genes that control cell cycle and DNA-repair pathways, with p53 signaling being the classical example, ${ }^{175,176}$ and even low doses of radiation have been found to induce expression of CDKN1A (a.k.a., CIP1, p21), DDB2, and XPC, all of which play direct or indirect roles in the p53 signaling pathway. ${ }^{177}$ The fact that such low doses of radiation exposure can induce significant expression changes may be directly relevant to expression studies of normal and abnormal hematopoietic cells. For example, at least one study has found that airline pilots have a relative increase frequency of number of chromosomal translocations in their peripheral blood cells, and retrospective analyses suggest that flight attendants may have a slightly higher risk of certain cancers. ${ }^{178,179}$

Investigators have also examined the effect of toxins, such as tobacco smoke, metal fumes, and bacterial endotoxins, on gene expression in human hematopoietic cells. ${ }^{180-182}$ Tobacco smoke inhalation clearly induces the expression of numerous genes in peripheral blood cells. ${ }^{183-185}$ Specifically, smoking promotes expression changes associated with the inflammatory response (increased CCR2 and IL1 $\beta$ ), carcinogen metabolism (increased CYP1B1), oxidative stress responses (increased SOD2), and apoptosis/cell cycle (increased CDKN2B). ${ }^{183,184}$ Physical displacement of populations of cells (for instance, due to local toxic damage/death or inflammatory cell recruitment) may be responsible for some of these expression changes; however, even in studies that carefully controlled for "cell population shifts," there continues to be smoking-related expression changes. ${ }^{185,186}$ These molecular changes certainly seem appropriate in light of data that indicate increased inflammation and DNAdamage within peripheral blood cells from tobacco smokers. ${ }^{187,188}$

A critical environmental factor, often overlooked in expression studies, is medications. Approximately $80 \%$ of people over the age of 18 take at least one medication each week, and the number of medications taken per individual increases with age, with $23 \%$ of women over the age of 65 years taking at least 5 medications. ${ }^{189}$ It is unknown how most medications impact the transcriptome in hematopoietic cells from healthy volunteers or patients. To complicate the matter further, recent studies reveal that some disorders may be associated with reproducible expression changes in the hematopoietic system, despite the absence of a known abnormal hematopoietic phenotype. For example, characteristic "abnormal" expression signatures in hematopoietic cells have now been identified for depression, bipolar disease, and psychosis. ${ }^{190}$ In the case of depression, drugs such as selective serotonin uptake inhibitors (SSRIs) decrease expression of serotonin transportors, ${ }^{191}$ and in fact, may reverse the underlying "abnormal" expression profile in the peripheral blood. ${ }^{190}$ Likewise, patients with bipolar disease or schizophrenia display increased transcription of dopamine D3 receptor (DRD3) in peripheral lymphocytes that also reverts back to near normal levels after treatment with antipsychotic medications. ${ }^{190}$

\section{LIMITATIONS AND FUTURE DIRECTIONS}


Expression in normal hematopoietic cells is a tightly controlled and poorly understood process, which is impacted by numerous factors including intrinsic changes within the cell (e.g., age) and environmental exposures (toxins, ligands, etc.). In addition, these expression responses must be overlaid upon the inherent genetic variation in the population. In order to better understand the interactions of genetics and environment on the hematopoietic organ, there is a crucial need for a more precise and detailed characterization of normal hematopoietic subpopulations. This includes the development of techniques to identify and isolate the most primitive hematopoietic stem cells. Advancements in the field of single-cell capture methods, as well as methods to perform wholesale genetic analyses on ever-lower amounts of DNA, RNA, and protein, hold considerable promise. In addition, there is a profound need to better understand how the micro- and macro-environment are controlling hematopoiesis. It is difficult to imagine that an isolated hematopoietic cell in culture has a similar or identical biological response as that same cell in the blood or bone marrow niche. In the future one can imagine that the study of peripheral blood gene expression will tell us much about disease propensity, potential treatment response and toxicity, and perhaps be a "canary" of environmental insult.

The authors have no conflict of interest to declare. 


\section{FIGURES}

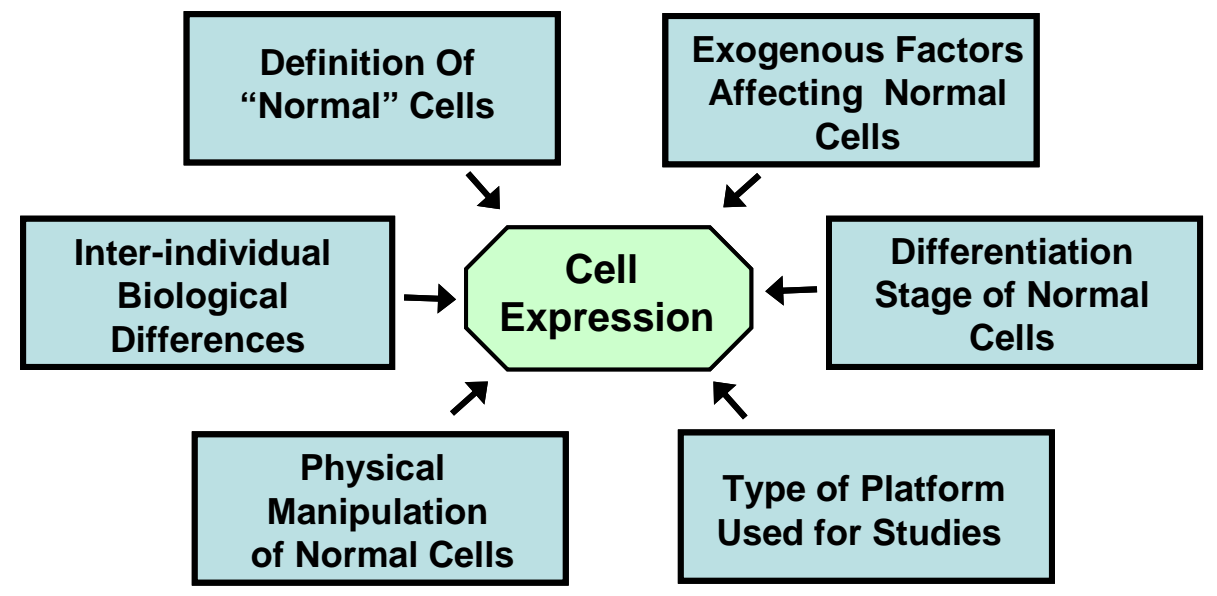

Figure 1: Factors To Be Considered When Examining Expression in Normal Cells- Figure illustrates a selection of the many factors influencing expression changes in normal and malignant hematopoietic cells. 




Figure 2: Intracellular and Extracellular Modulators of Gene Expression in Normal Hematopoietic CellsFigure shows a simplified illustration of the complex nature of expression in normal hematopoietic cells. Multiple exogenous factors, such as adhesion molecules (purple), cytokines/growth factors (green) and environmental exposures (yellow) are constantly impacting the expression signature. Chromatin structure controls the accessibility of transcription factors (TF, light blue) and the transcription complex (TC, gray) to the DNA. Methylation of CpG islands in promoter regions and other parts of the gene also limit the ability of TF and TC to bind to the DNA. Once RNA is made, it migrates outside of the nucleus, where other post-transcriptional regulators, such as microRNAs (black sequence), influence the expression and ability of the RNA to be translated. In addition, it is here that many of the critical post-translational modifications occur (not shown). 


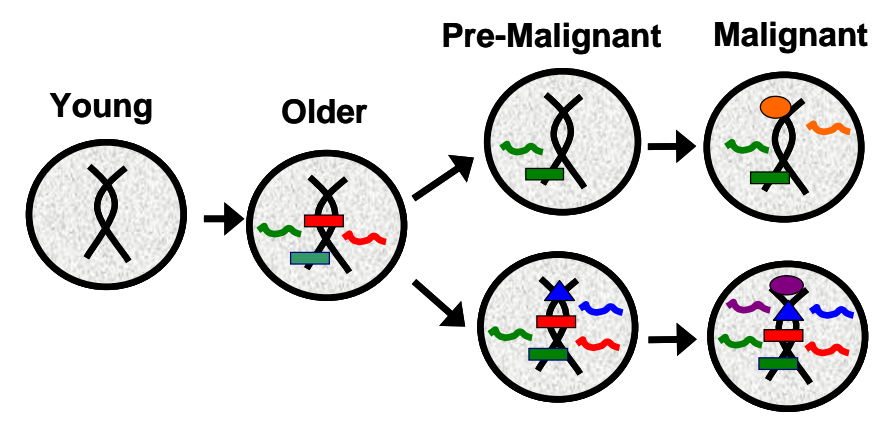

Figure 3: Model of Malignant Transformation in Older Patients- As humans age, HSCs acquire age-related genetic and epigenetic changes (red and green rectangle), which produce ARECs that either protect cells from transformation (red line, P-ARECs) or promote transformation (green line, T-ARECs). In some cases, the PARECs are lost either through genetic or epigenetic changes, resulting in a pre-malignant phenotype that transforms with additional changes (orange). Even if the P-ARECs are not lost, T-ARECs may promote the acquisition of additional genetic and epigenetic changes (blue triangle and purple circle), which facilitate the development of pre-malignant and eventually, malignant clones. 
Table 1. Type of Membrane Bound Receptors on Hematopoietic Cells.

\begin{tabular}{|c|c|c|c|c|c|c|}
\hline \multicolumn{4}{|l|}{ Receptor } & \multicolumn{3}{|l|}{ Ligand } \\
\hline Name & Symbol & Alias & Family & Name & Symbol & Alias \\
\hline \multicolumn{4}{|c|}{ Receptor Tyrosine Kinase (RTK). All 5 members of RTK family. ${ }^{57,71-73}$} & Ligand & & \\
\hline $\begin{array}{l}\text { v-kit Hardy-Zuckerman } 4 \text { feline } \\
\text { sarcoma viral oncogene homolog }\end{array}$ & KIT & CD117, C-KIT & PDGFR, RTK III & KIT ligand & KITLG & $\mathrm{SCF}, \mathrm{KL}-1$ \\
\hline $\begin{array}{l}\text { Platelet-derived growth factor } \\
\text { receptor, alpha }{ }^{192}\end{array}$ & PDGFRA & CD140A & PDGFR, RTK III & $\begin{array}{l}\text { Platelet-derived growth } \\
\text { factor, alpha }\end{array}$ & PDGFA & \\
\hline $\begin{array}{l}\text { Platelet-derived growth factor } \\
\text { receptor, beta }\end{array}$ & PDGFRB & CD140B & PDGFR, RTK III & $\begin{array}{l}\text { Platelet-derived growth } \\
\text { factor, beta }\end{array}$ & PDGFB & SIS, SSV \\
\hline FMS-related tyrosine kinase $3^{192}$ & FLT3 & CD135, FLK2 & PDGFR, RTK III & FLT3 ligand & FLT3LG & $\mathrm{FL}$ \\
\hline Colony stimulating factor 1 receptor & CSF1R & CD115, FMS & PDGFR, RTK III & $\begin{array}{l}\text { Colony stimulating factor } \\
\text { (macrophage) }\end{array}$ & CSF1 & MCSF \\
\hline \multicolumn{4}{|c|}{ Cytokine Receptors (CKRs). Selected set of CKRs involved in hematopoiesis. ${ }^{58,59,193}$} & Ligand & & \\
\hline \multirow[t]{2}{*}{$\begin{array}{l}\text { Colony stimulating factor } 2 \\
\text { receptor, composed of two different } \\
\text { subunits }{ }^{194,195}\end{array}$} & $\begin{array}{l}\text { CSF2RA, Unique } \\
\text { to CSFR }\end{array}$ & $\begin{array}{l}\text { CD116, } \\
\text { GMCSFR }\end{array}$ & \multirow[t]{2}{*}{$\begin{array}{l}\text { Cytokine Receptor } \\
\text { Superfamily, Type 1, } \\
\text { CKR I }\end{array}$} & \multirow[t]{2}{*}{$\begin{array}{l}\text { Colony stimulating factor } \\
\text { (granulocyte - } \\
\text { macrophage) }\end{array}$} & \multirow[t]{2}{*}{ CSF2 } & \multirow[t]{2}{*}{ GMCSF } \\
\hline & $\begin{array}{l}\text { CSF2RB, } \\
\text { Common also to } \\
\text { IL3 and IL5 } \\
\text { receptors }\end{array}$ & $\begin{array}{l}\text { CD131, IL3RB, } \\
\text { IL5RB }\end{array}$ & & & & \\
\hline Colony stimulating factor 3 receptor & CSF3R & CD114, GCSFR & CKR I & $\begin{array}{l}\text { Colony stimulating factor } \\
\text { (granulocyte) }\end{array}$ & CSF3 & GCSF \\
\hline Erythropoietin receptor & EPOR & ------------ & CKR I & Erythropoietin & EPO & --------- \\
\hline $\begin{array}{l}\text { Myeloproliferative leukemia virus } \\
\text { oncogene }\end{array}$ & MPL & CD110, TPOR & CKRI & Thrombopoietin & THPO & TPO \\
\hline $\begin{array}{l}\text { Interleukin receptors (Most } \\
\text { interleukin receptors but not IL } 10 \text { or } \\
\text { IL 20) }\end{array}$ & $\begin{array}{l}\text { IL2RA, IL2RB, } \\
\text { IL2RG, IL3RA, } \\
\text { IL6R respectively }\end{array}$ & $\begin{array}{l}\text { CD25, CD122, } \\
\text { CD132, CD123, } \\
\text { CD126 } \\
\text { respectively }\end{array}$ & CKR I & $\begin{array}{l}\text { Interleukin 2, Interleukin } \\
3 \text {, Interleukin } 6\end{array}$ & $\begin{array}{l}\text { IL2, IL3, a } \\
\text { to their ap } \\
\text { receptors. }\end{array}$ & $\begin{array}{l}\text { d IL } 6 \text { bind } \\
\text { ropriate }\end{array}$ \\
\hline Interferon receptors, IL10, and IL20 & $\begin{array}{l}\text { IFNAR1,IFNAR2, } \\
\text { IFNGR1,IFNGR2 }\end{array}$ & $\begin{array}{l}\text { IFNGR1 } \\
(\text { CD119) }\end{array}$ & CKR 2 & $\begin{array}{l}\text { Interferon alpha, } \\
\text { interferon beta, } \\
\text { interferon gamma }\end{array}$ & $\begin{array}{l}\text { IFNA and } \\
\text { IFNAR1/2 } \\
\text { IFNGR1/2 }\end{array}$ & $\begin{array}{l}\text { =NB bind } \\
\text { IFNG binds }\end{array}$ \\
\hline \multicolumn{4}{|c|}{$\begin{array}{l}\text { Protein Tyrosine Phosphatatases Receptors (PTPRs). Selected members from } 38 \text { classical } \\
\text { PTPRs. }{ }^{60,61}\end{array}$} & \multicolumn{3}{|l|}{ Ligand } \\
\hline $\begin{array}{l}\text { Protein tyrosine phosphatase, } \\
\text { receptor type, C }\end{array}$ & PTPRC & CD45, LCA & Receptor Type I & \multirow{2}{*}{\multicolumn{3}{|c|}{$\begin{array}{l}\text { Specific ligands are not well characterized for } \\
\text { PTPRs. Many PTPRs interact and regulate other } \\
\text { molecules/receptors in the cell membrane or are } \\
\text { involved in cell-cell and cell-matrix interactions. } \\
\text { There is also a separate class of non-receptor } \\
\text { protein tyrosine phosphatases (PTPNs). }\end{array}$}} \\
\hline $\begin{array}{l}\text { Protein tyrosine phosphatase, } \\
\text { receptor type, F }\end{array}$ & PTPRF & LAR & Receptor Type II & & & \\
\hline \multicolumn{4}{|l|}{ TGF- $\beta$ Superfamily of Receptors ${ }^{62,196}$} & \multicolumn{3}{|l|}{ Ligand } \\
\hline $\begin{array}{l}\text { Transforming growth factor Beta } \\
\text { Receptor I }\end{array}$ & TGFBR1 & ALK5 & Type 1 Receptors & \multirow{5}{*}{\multicolumn{3}{|c|}{$\begin{array}{l}\text { Numerous ligands that bind to the various } \\
\text { combinations of receptors. In most cases, a type } 1 \\
\text { receptor will pair with a type } 2 \text { receptor to form the } \\
\text { functioning receptor complex. Some ligands } \\
\text { include TGF } \beta 1 \text {, TGF } \beta 2 \text {, TGF } \beta 3 \text {, activin } \beta_{A} \text {, activin } \\
\beta_{B} \text {, activin } \beta_{C} \text {, nodal, BMP2 - } 7 \text {, GDFs, and AMH. }\end{array}$}} \\
\hline $\begin{array}{l}\text { Specific activin receptor-like } \\
\text { kinases (ACVRL) and activin } \\
\text { receptors (ACVR) }\end{array}$ & $\begin{array}{l}\text { ACVRL1, } \\
\text { ACVR1, } \\
\text { ACVR1B, } \\
\text { ACVR1C }\end{array}$ & $\begin{array}{l}\text { ALK1, ALK2, } \\
\text { ALK4, ALK7 } \\
\text { respectively }\end{array}$ & Type 1 Receptors & & & \\
\hline $\begin{array}{l}\text { Bone morphogenetic protein } \\
\text { receptors (BMPR) }\end{array}$ & $\begin{array}{l}\text { BMPR1A, } \\
\text { BMPR1B }\end{array}$ & $\begin{array}{l}\text { ALK3, ALK6 } \\
\text { respectively }\end{array}$ & Type 1 Receptors & & & \\
\hline $\begin{array}{l}\text { Transforming growth factor Beta } \\
\text { Receptor I }\end{array}$ & TGFBR2 & TGFßRII & Type 2 Receptors & & & \\
\hline Activin receptors (ACVR) & $\begin{array}{l}\text { ACVR2, } \\
\text { ACVR2B }\end{array}$ & $\begin{array}{l}\text { ACTRII, } \\
\text { ACTRIIB }\end{array}$ & Type 2 Receptors & & & \\
\hline
\end{tabular}




\begin{tabular}{|c|c|c|c|c|}
\hline $\begin{array}{l}\text { Bone morphogenetic protein } \\
\text { receptors } 2\end{array}$ & BMPR2 & BMPRII & Type 2 Receptors & \\
\hline Anti-Mullerian hormone receptor 2 & AMHR2 & MISRII & Type 2 Receptors & \\
\hline \multicolumn{4}{|c|}{ TNF Receptors (Selected members from more than 29 different TNF receptors) ${ }^{63,64}$} & Ligand \\
\hline Tumor necrosis factor receptor 1 & TNFR1 & CD120a & ------------ & \multirow{2}{*}{$\begin{array}{l}\text { Both TNF (a.k.a. TNFA, TNF- } \alpha \text { ) and TNFB can } \\
\text { bind to either receptor. }\end{array}$} \\
\hline Tumor necrosis factor receptor 2 & TNFR2 & CD120b & ----------- & \\
\hline $\begin{array}{l}\text { Tumor necrosis factor receptor, } \\
\text { superfamily } 10 \mathrm{~A}\end{array}$ & TNFRSF10A & $\begin{array}{l}\text { CD261, DR4, } \\
\text { TRAILR1 }\end{array}$ & ------------ & \multirow{2}{*}{$\begin{array}{l}\text { Tumor necrosis factor ligand superfamily, member } \\
10 \text { (aka TNF-related apoptosis- inducing ligand, } \\
\text { TRAIL) binds to both receptors. }\end{array}$} \\
\hline $\begin{array}{l}\text { Tumor necrosis factor receptor, } \\
\text { superfamily } 10 B\end{array}$ & TNFRSF10B & $\begin{array}{l}\text { CD262, DR5, } \\
\text { TRAILR2 }\end{array}$ & ----------- & \\
\hline \multicolumn{4}{|l|}{ Notch Receptors ${ }^{51,65,197}$} & Ligand \\
\hline Notch homolog, 1 - 4 & $\begin{array}{l}\text { NOTCH1- } \\
\text { NOTCH4 }\end{array}$ & ------------ & $\begin{array}{l}\text { Type } 1 \\
\text { Transmembrane } \\
\text { Receptors }\end{array}$ & $\begin{array}{l}\text { Delta-like family of ligands (DLL1, DLL3, DLL4) and } \\
\text { Jagged family (JAG1, JAG2) bind Notch } \\
\text { Receptors. }\end{array}$ \\
\hline \multicolumn{4}{|c|}{ Wingless-type MMTV integration site family members (WNT) Receptors ${ }^{66,198}$} & Ligand \\
\hline Frizzled homolog, $1-10^{199,200}$ & FZD1 - FZD10, & ------------ & $\begin{array}{l}\text { G-Protein-coupled } \\
\text { Receptors, Class } 6\end{array}$ & \multirow{2}{*}{$\begin{array}{l}\text { FZD and LRP combine to form a receptor complex } \\
\text { that binds to Wingless-type MMTV integration site } \\
\text { family members (WNTs) }\end{array}$} \\
\hline $\begin{array}{l}\text { Low density lipoprotein receptor- } \\
\text { related protein, } 5 \text { and } 6^{201}\end{array}$ & LRP5 and LRP6 & $\begin{array}{l}\text { LRP5 (a.k.a., } \\
\text { BMND1, EVR1); } \\
\text { LRP6 (a.k.a., } \\
\text { ADCAD2) }\end{array}$ & ------------ & \\
\hline \multicolumn{4}{|c|}{ CXC Chemokine Receptors (Selected members from the 6 known CXCRs) ${ }^{67}$} & Ligand \\
\hline CXC chemokine receptor 4 & CXCR4 & CD184, Fusin & \multirow{2}{*}{$\begin{array}{l}\text { G-Protein-coupled } \\
\text { Receptors, Class 1, } \\
\text { Subfamily A2 }\end{array}$} & Binds C-X-C motif ligands, 12; CXCL12 \\
\hline CXC chemokine receptor 5 & CXCR5 & $\begin{array}{l}\text { CD185, Burkitts } \\
\text { lymphoma } \\
\text { receptor } 1\end{array}$ & & Binds C-X-C motif ligands, 15; CXCL15 \\
\hline \multicolumn{4}{|c|}{ Chemokine Receptors (Selected members from the 10 known CCRs) ${ }^{68}$} & Ligand \\
\hline Chemokine receptor 1 & CCR1 & CD191 & \multirow{2}{*}{$\begin{array}{l}\text { G-Protein-coupled } \\
\text { Receptors, Class } 1 \\
\text { Subfamily A1 }\end{array}$} & Binds C-C motif ligands, 3 or 5 ; CCL3, CCL5 \\
\hline Chemokine receptor 2 & CCR2 & CD192 & & Binds C-C motif ligands, 2; CCL2 \\
\hline
\end{tabular}




\begin{tabular}{|c|c|c|c|c|c|}
\hline \multicolumn{6}{|l|}{ Assessing Genomic Changes: } \\
\hline Genomic & Throughput & Resolution & $\begin{array}{l}\text { Material } \\
\text { Required }\end{array}$ & Limitations & Data Provided \\
\hline Pyrosequencing & High & Primary Sequence & $\begin{array}{l}\text { DNA, } \\
\text { nanograms }\end{array}$ & Expense & Complete Sequence \\
\hline SNP Arrays & High & $\begin{array}{l}\text { Up to } 1 \text { million SNPs per } \\
\text { Genome }\end{array}$ & $\begin{array}{l}\text { DNA, } \\
\text { nanograms }\end{array}$ & Expense & $\begin{array}{l}\text { SNP variation, CNV, } \\
\text { LOH }\end{array}$ \\
\hline PCR/Sequencing & Moderate-low & Primary Sequence & $\begin{array}{l}\text { DNA, } \\
\text { picograms }\end{array}$ & $\begin{array}{l}\text { Limited number of } \\
\text { genes }\end{array}$ & $\begin{array}{l}\text { Sequence between } \\
\text { primers }\end{array}$ \\
\hline Epigenetics & Throughput & Max Resolution & $\begin{array}{l}\text { Material } \\
\text { Required }\end{array}$ & Limitations & Data Provided \\
\hline Methylation Arrays & High & Increasing & $\begin{array}{l}\text { DNA, } \\
\text { nanograms }\end{array}$ & $\begin{array}{l}\text { Requires sequence } \\
\text { modifications }\end{array}$ & $\begin{array}{l}\text { Methylation at } \mathrm{CpG} \\
\text { islands }\end{array}$ \\
\hline Methylation-specific PCR & Low & Specific target sequence & $\begin{array}{l}\text { DNA, } \\
\text { nanograms }\end{array}$ & $\begin{array}{l}\text { Requires sequence } \\
\text { modifications }\end{array}$ & $\begin{array}{l}\text { Methylation at } \mathrm{CpG} \\
\text { islands }\end{array}$ \\
\hline $\begin{array}{l}\text { Methylation-specific Restriction } \\
\text { Enzyme Protection PCR Assays }\end{array}$ & Low & Specific target sequence & $\begin{array}{l}\text { DNA, } \\
\text { nanograms }\end{array}$ & $\begin{array}{l}\text { Requires methylation } \\
\text { be at restriction site }\end{array}$ & $\begin{array}{l}\text { Methylation at restriction } \\
\text { enzyme cutting sites }\end{array}$ \\
\hline CHiP-on-chip Assay & High & $\begin{array}{l}>200,000 \text { specific DNA } \\
\text { and/or promoter } \\
\text { sequences }\end{array}$ & $\begin{array}{l}\text { Cells, } \\
\geq 10,000\end{array}$ & $\begin{array}{l}\text { Antibody quality and } \\
\text { technically challenging }\end{array}$ & $\begin{array}{l}\text { DNA sites of histone } \\
\text { binding and type of } \\
\text { histone }\end{array}$ \\
\hline \multicolumn{6}{|l|}{ Assessing Transcriptome Changes: } \\
\hline Transcription & Throughput & Max Resolution & $\begin{array}{l}\text { Material } \\
\text { Required }\end{array}$ & Limitations & Data Provided \\
\hline Whole transcriptome sequencing & High & Primary sequence & $\begin{array}{l}\text { RNA, } \\
\text { nanograms }\end{array}$ & Cost & All transcript isoforms \\
\hline RNA and microRNA arrays & High & $\begin{array}{l}>20,000 \text { transcripts and/or } \\
\text { genes }\end{array}$ & $\begin{array}{l}\text { RNA, } \\
\text { micro - } \\
\text { nanograms }\end{array}$ & $\begin{array}{l}\text { Cost, miss genes or } \\
\text { isoforms not included } \\
\text { on array }\end{array}$ & $\begin{array}{l}\text { Quantitative expression } \\
\text { of transcripts included } \\
\text { on the array }\end{array}$ \\
\hline RT/PCR amplification & Moderate & Selected gene & $\begin{array}{l}\text { RNA, } \\
\text { picograms }\end{array}$ & $\begin{array}{l}\text { Not useful for } \\
\text { discovery studies }\end{array}$ & $\begin{array}{l}\text { Quantitative expression } \\
\text { of gene }\end{array}$ \\
\hline \multicolumn{6}{|l|}{ Assessing Proteomic Changes: } \\
\hline Mass Spectrometry based & Throughput & Max Resolution & $\begin{array}{l}\text { Material } \\
\text { Required }\end{array}$ & Limitations & Data Provided \\
\hline Peptide fingerprinting & High & Digested peptides & $\begin{array}{l}\text { Protein, low } \\
\text { amounts }\end{array}$ & $\begin{array}{l}\text { Limited to known } \\
\text { peptides in database }\end{array}$ & $\begin{array}{l}\text { Potentially identifiable } \\
\text { fragments of protein }\end{array}$ \\
\hline MALDI-TOF or SELDI-TOF & High & Digested peptides & $\begin{array}{l}\text { Protein, low } \\
\text { amounts }\end{array}$ & $\begin{array}{l}\text { Limited to known } \\
\text { peptides in database }\end{array}$ & $\begin{array}{l}\text { Protein interaction, } \\
\text { dissociation constants, } \\
\text { manifold applications }\end{array}$ \\
\hline Microarray & High & $\begin{array}{l}\text { Any protein recognized by } \\
\text { available antibodies }\end{array}$ & $\begin{array}{l}\text { Protein, low } \\
\text { amounts }\end{array}$ & Limited by antibodies & Protein expression \\
\hline $\begin{array}{l}\text { Electrophoresis and Antibody } \\
\text { based }\end{array}$ & Throughput & Max Resolution & $\begin{array}{l}\text { Material } \\
\text { Required }\end{array}$ & Limitations & Data Provided \\
\hline Two-dimensional electrophoresis & Moderate-low & $\begin{array}{l}\text { Separation of potentially } \\
1000 \text { s of proteins }\end{array}$ & $\begin{array}{l}\text { Protein, } \\
\text { micrograms }\end{array}$ & $\begin{array}{l}\text { Potential protein co- } \\
\text { migration }\end{array}$ & $\begin{array}{l}\text { Separation of protein by } \\
\text { isoelectic point and } \\
\text { molecular weight }\end{array}$ \\
\hline Western Blotting & Low & Specific proteins & $\begin{array}{l}\text { Protein, } \\
\text { micrograms }\end{array}$ & $\begin{array}{l}\text { Antibody specificity } \\
\text { and sensitivity }\end{array}$ & $\begin{array}{l}\text { Semi-quantification of } \\
\text { protein expression }\end{array}$ \\
\hline Immunoprecipitation & Moderate-low & Specific proteins & $\begin{array}{l}\text { Protein, } \\
\text { micrograms }\end{array}$ & $\begin{array}{l}\text { Antibody specificity } \\
\text { and sensitivity }\end{array}$ & $\begin{array}{l}\text { Protein expression and } \\
\text { binding partners }\end{array}$ \\
\hline ELISA & High-moderate & Specific proteins & $\begin{array}{l}\text { Protein, } \\
\text { nanogram }\end{array}$ & $\begin{array}{l}\text { Antibody specificity } \\
\text { and sensitivity }\end{array}$ & $\begin{array}{l}\text { presence of a specific } \\
\text { protein }\end{array}$ \\
\hline
\end{tabular}


(1) Radich JP, Dai H, Mao M et al. Gene expression changes associated with progression and response in chronic myeloid leukemia. Proc Natl Acad Sci U S A. 2006;103:2794-2799.

(2) Valk PJ, Verhaak RG, Beijen MA et al. Prognostically useful gene-expression profiles in acute myeloid leukemia. N Engl J Med. 2004;350:1617-1628.

(3) Stirewalt DL, Meshinchi S, Kopecky KJ et al. Identification of genes with abnormal expression changes in acute myeloid leukemia. Genes Chromosomes Cancer. 2008;47:8-20.

(4) Robinson Y, Matenov A, Tschoke SK et al. Impaired erythropoiesis after haemorrhagic shock in mice is associated with erythroid progenitor apoptosis in vivo. Acta Anaesthesiol Scand. 2008;52:605-613.

(5) Jirtle RL, Skinner MK. Environmental epigenomics and disease susceptibility. Nat Rev Genet. 2007;8:253-62.

(6) Lu SJ, Li F, Vida L, Honig GR. CD34+CD38- hematopoietic precursors derived from human enbryonic stem cells exhibit an embryonic gene expression pattern. Blood. 2004;103:4134-4141.

(7) Georgantas RW, III, Tanadve V, Malehorn M et al. Microarray and serial analysis of gene expression analyses identify known and novel transcripts overexpressed in hematopoietic stem cells. Cancer Res. 2004;64:4434-4441.

*(8) Gal H, Amariglio N, Trakhtenbrot L et al. Gene expression profiles of AML derived stem cells; similarity to hematopoietic stem cells. Leukemia. 2006;20:2147-2154.

*(9) Wood BL, Arroz M, Barnett D et al. 2006 Bethesda International Consensus recommendations on the immunophenotypic analysis of hematolymphoid neoplasia by flow cytometry: optimal reagents and reporting for the flow cytometric diagnosis of hematopoietic neoplasia. Cytometry B Clin Cytom. 2007;72 Suppl 1:14-22.

(10) Mutter GL, Zahrieh D, Liu C et al. Comparison of frozen and RNALater solid tissue storage methods for use in RNA expression microarrays. BMC Genomics. 2004;5:88.

(11) lafrate AJ, Feuk L, Rivera MN et al. Detection of large-scale variation in the human genome. Nat Genet. 2004;36:949-951.

(12) Sebat J, Lakshmi B, Troge J et al. Large-scale copy number polymorphism in the human genome. Science. 2004;305:525-528.

(13) Bruder CE, Piotrowski A, Gijsbers AA et al. Phenotypically concordant and discordant monozygotic twins display different DNA copy-number-variation profiles. Am J Hum Genet. 2008;82:763-771. 
(14) Salipante SJ, Horwitz MS. A phylogenetic approach to mapping cell fate. Curr Top Dev Biol. 2007;79:157-184.

(15) Nilsson-Ehle $\mathrm{H}$, Swolin B, Westin J. Bone marrow progenitor cell growth and karyotype changes in healthy 88-year-old subjects. Eur J Haematol. 1995;55:14-18.

(16) Rossi DJ, Bryder D, Seita J et al. Deficiencies in DNA damage repair limit the function of haematopoietic stem cells with age. Nature. 2007;447:725-729.

(17) Flores M, Morales L, Gonzaga-Jauregui $C$ et al. Recurrent DNA inversion rearrangements in the human genome. Proc Natl Acad Sci U S A. 2007;104:6099-6106.

*(18) Cotton RG, Auerbach AD, Axton M et al. GENETICS. The Human Variome Project. Science. 2008;322:861-862.

(19) Spivakov M, Fisher AG. Epigenetic signatures of stem-cell identity. Nat Rev Genet. 2007;8:263271.

(20) Cedar H, Bergman Y. Linking DNA methylation and histone modification: patterns and paradigms. Nat Rev Genet. 2009.

(21) Probst AV, Dunleavy E, Almouzni G. Epigenetic inheritance during the cell cycle. Nat Rev Mol Cell Biol. 2009;10:192-206.

(22) Klose RJ, Zhang Y. Regulation of histone methylation by demethylimination and demethylation. Nat Rev Mol Cell Biol. 2007;8:307-318.

(23) Misteli T, Soutoglou E. The emerging role of nuclear architecture in DNA repair and genome maintenance. Nat Rev Mol Cell Biol. 2009;10:243-254.

(24) Jiang C, Pugh BF. Nucleosome positioning and gene regulation: advances through genomics. Nat Rev Genet. 2009;10:161-172.

(25) Henikoff S. Nucleosome destabilization in the epigenetic regulation of gene expression. Nat Rev Genet. 2008;9:15-26.

(26) Shi Y. Histone lysine demethylases: emerging roles in development, physiology and disease. Nat Rev Genet. 2007;8:829-833.

(27) Bolden JE, Peart MJ, Johnstone RW. Anticancer activities of histone deacetylase inhibitors. Nat Rev Drug Discov. 2006;5:769-784.

(28) Darnell JE, Jr. Transcription factors as targets for cancer therapy. Nat Rev Cancer. 2002;2:740749.

(29) Wei $\mathrm{CL}$, Wu Q, Vega VB et al. A global map of p53 transcription-factor binding sites in the human genome. Cell. 2006;124:207-219. 
(30) Cawley S, Bekiranov S, Ng HH et al. Unbiased mapping of transcription factor binding sites along human chromosomes 21 and 22 points to widespread regulation of noncoding RNAs. Cell. 2004;116:499-509.

(31) Payne KJ, Huang G, Sahakian E et al. Ikaros isoform $\mathrm{x}$ is selectively expressed in myeloid differentiation. J Immunol. 2003;170:3091-3098.

(32) Georgopoulos K. Haematopoietic cell-fate decisions, chromatin regulation and ikaros. Nat Rev Immunol. 2002;2:162-174.

(33) Erdmann VA, Szymanski M, Hochberg A, de Groot N, Barciszewski J. Collection of mRNA-like non-coding RNAs. Nucleic Acids Res. 1999;27:192-5.

(34) Dermitzakis ET, Reymond A, Scamuffa $\mathrm{N}$ et al. Evolutionary discrimination of mammalian conserved non-genic sequences (CNGs). Science. 2003;302:1033-5.

(35) Reinhart BJ, Slack FJ, Basson $\mathrm{M}$ et al. The 21-nucleotide let-7 RNA regulates developmental timing in Caenorhabditis elegans. Nature. 2000;403:901-6.

*(36) Chen CZ, Li L, Lodish HF, Bartel DP. MicroRNAs modulate hematopoietic lineage differentiation. Science. 2004;303:83-86.

(37) Lim LP, Lau NC, Garrett-Engele P et al. Microarray analysis shows that some microRNAs downregulate large numbers of target mRNAs. Nature. 2005;433:769-73.

(38) Lai EC. Micro RNAs are complementary to 3' UTR sequence motifs that mediate negative posttranscriptional regulation. Nat Genet. 2002;30:363-4.

(39) Georgantas RW3, Hildreth R, Morisot S et al. CD34+ hematopoietic stem-progenitor cell microRNA expression and function: a circuit diagram of differentiation control. Proc Natl Acad Sci U S A. 2007;104:2750-5.

(40) Wang $X$, Arai S, Song $X$ et al. Induced ncRNAs allosterically modify RNA-binding proteins in cis to inhibit transcription. Nature. 2008;454:126-30.

(41) Pieroni E, de la Fuente van Bentem, Mancosu G et al. Protein networking: insights into global functional organization of proteomes. Proteomics. 2008;8:799-816.

(42) Blom N, Sicheritz-Ponten T, Gupta R, Gammeltoft S, Brunak S. Prediction of post-translational glycosylation and phosphorylation of proteins from the amino acid sequence. Proteomics. 2004;4:1633-1649.

(43) Lin $\mathrm{CY}$, Chin $\mathrm{CH}, \mathrm{Wu} \mathrm{HH}$ et al. Hubba: hub objects analyzer--a framework of interactome hubs identification for network biology. Nucleic Acids Res. 2008;36:W438-W443.

(44) Sanguinetti G, Noirel J, Wright PC. MMG: a probabilistic tool to identify submodules of metabolic pathways. Bioinformatics. 2008;24:1078-1084. 
(45) Margolin AA, Wang K, Lim WK et al. Reverse engineering cellular networks. Nat Protoc. 2006;1:662-671.

(46) Vakhrushev SY, Dadimov D, Peter-Katalinic J. Software Platform for High-Throughput Glycomics. Anal Chem. 2009.

(47) Hergenrother PJ. Obtaining and screening compound collections: a user's guide and a call to chemists. Curr Opin Chem Biol. 2006;10:213-218.

(48) Rossi D, Rasi S, Franceschetti S et al. Analysis of the host pharmacogenetic background for prediction of outcome and toxicity in diffuse large B-cell lymphoma treated with R-CHOP21. Leukemia. 2009.

(49) Amsen D, Antov A, Flavell RA. The different faces of Notch in T-helper-cell differentiation. Nat Rev Immunol. 2009;9:116-24.

(50) Allen JA, Halverson-Tamboli RA, Rasenick MM. Lipid raft microdomains and neurotransmitter signalling. Nat Rev Neurosci. 2007;8:128-40.

(51) Bray SJ. Notch signalling: a simple pathway becomes complex. Nat Rev Mol Cell Biol. 2006;7:67889.

(52) Guo W, Giancotti FG. Integrin signalling during tumour progression. Nat Rev Mol Cell Biol. 2004;5:816-26.

(53) Kholodenko BN. Cell-signalling dynamics in time and space. Nat Rev Mol Cell Biol. 2006;7:16576.

(54) McKay MM, Morrison DK. Integrating signals from RTKs to ERK/MAPK. Oncogene. 2007;26:311321.

(55) Wood BL. Ten-color immunophenotyping of hematopoietic cells. Curr Protoc Cytom. 2005;Chapter 6:Unit6 21.

(56) Massie C, Mills IG. The developing role of receptors and adaptors. Nat Rev Cancer. 2006;6:403-9.

(57) Stirewalt DL, Radich JP. The role of FLT3 in haematopoietic malignancies. Nat Rev Cancer. 2003;3:650-65.

(58) Robb L. Cytokine receptors and hematopoietic differentiation. Oncogene. 2007;26:6715-23.

(59) Hamilton JA. Colony-stimulating factors in inflammation and autoimmunity. Nat Rev Immunol. 2008;8:533-44.

(60) Fischer EH, Charbonneau H, Tonks NK. Protein tyrosine phosphatases: a diverse family of intracellular and transmembrane enzymes. Science. 1991;253:401-6.

(61) Ostman A, Hellberg C, Bohmer FD. Protein-tyrosine phosphatases and cancer. Nat Rev Cancer. 2006;6:307-20. 
(62) Schmierer B, Hill CS. TGFbeta-SMAD signal transduction: molecular specificity and functional flexibility. Nat Rev Mol Cell Biol. 2007;8:970-82.

(63) Aggarwal BB. Signalling pathways of the TNF superfamily: a double-edged sword. Nat Rev Immunol. 2003;3:745-56.

(64) Croft M. The role of TNF superfamily members in T-cell function and diseases. Nat Rev Immunol. 2009;9:271-85.

(65) D'Souza B, Miyamoto A, Weinmaster G. The many facets of Notch ligands. Oncogene. 2008;27:5148-67.

(66) Staal FJ, Luis TC, Tiemessen MM. WNT signalling in the immune system: WNT is spreading its wings. Nat Rev Immunol. 2008;8:581-93.

(67) Homey B, Muller A, Zlotnik A. Chemokines: agents for the immunotherapy of cancer? Nat Rev Immunol. 2002;2:175-84.

(68) Dorsam RT, Gutkind JS. G-protein-coupled receptors and cancer. Nat Rev Cancer. 2007;7:79-94.

(69) Medzhitov R. Toll-like receptors and innate immunity. Nat Rev Immunol. 2001;1:135-45.

(70) Turner M, Billadeau DD. VAV proteins as signal integrators for multi-subunit immunerecognition receptors. Nat Rev Immunol. 2002;2:476-86.

(71) Agnes F, Shamoon B, Dina C et al. Genomic structure of the downstream part of the human FLT3 gene: exon/intron structure conservation among genes encoding receptor tyrosine kinases (RTK) of subclass III. Gene. 1994;145:283-8.

(72) Robinson DR, Wu YM, Lin SF. The protein tyrosine kinase family of the human genome. Oncogene. 2000;19:5548-57.

(73) Li E, Hristova K. Role of receptor tyrosine kinase transmembrane domains in cell signaling and human pathologies. Biochemistry. 2006;45:6241-51.

(74) Yu X, Zou J, Ye Z et al. Notch signaling activation in human embryonic stem cells is required for embryonic, but not trophoblastic, lineage commitment. Cell Stem Cell. 2008;2:461-71.

(75) Maillard I, Koch U, Dumortier A et al. Canonical notch signaling is dispensable for the maintenance of adult hematopoietic stem cells. Cell Stem Cell. 2008;2:356-66.

(76) Delaney C, Varnum-Finney B, Aoyama K, Brashem-Stein C, Bernstein ID. Dose-dependent effects of the Notch ligand Delta1 on ex vivo differentiation and in vivo marrow repopulating ability of cord blood cells. Blood. 2005;106:2693-2699.

(77) Hinds DA, Kloek AP, Jen M, Chen X, Frazer KA. Common deletions and SNPs are in linkage disequilibrium in the human genome. Nat Genet. 2006;38:82-85.

(78) Syvanen AC. Toward genome-wide SNP genotyping. Nat Genet. 2005;37 Suppl:S5-10. 
(79) Altug-Teber O, Dufke A, Poths S et al. A rapid microarray based whole genome analysis for detection of uniparental disomy. Hum Mutat. 2005;26:153-159.

(80) Green RE, Krause J, Ptak SE et al. Analysis of one million base pairs of Neanderthal DNA. Nature. 2006;444:330-336.

(81) Ley TJ, Mardis ER, Ding L et al. DNA sequencing of a cytogenetically normal acute myeloid leukaemia genome. Nature. 2008;456:66-72.

(82) Sultan $\mathrm{M}$, Schulz $\mathrm{MH}$, Richard $\mathrm{H}$ et al. A global view of gene activity and alternative splicing by deep sequencing of the human transcriptome. Science. 2008;321:956-960.

(83) McCarroll SA, Kuruvilla FG, Korn JM et al. Integrated detection and population-genetic analysis of SNPs and copy number variation. Nat Genet. 2008;40:1166-1174.

(84) Neil H, Malabat C, d'Aubenton-Carafa $Y$ et al. Widespread bidirectional promoters are the major source of cryptic transcripts in yeast. Nature. 2009;457:1038-1042.

(85) Allen RC, Zoghbi HY, Moseley AB, Rosenblatt HM, Belmont JW. Methylation of Hpall and Hhal sites near the polymorphic CAG repeat in the human androgen-receptor gene correlates with $\mathrm{X}$ chromosome inactivation. Am J Hum Genet. 1992;51:1229-1239.

(86) Felgner J, Heidorn K, Korbacher D, Frahm SO, Parwaresch R. Cell lineage specificity in G-CSF receptor gene methylation. Leukemia. 1999;13:530-4.

(87) Herman JG, Graff JR, Myohanen S, Nelkin BD, Baylin SB. Methylation-specific PCR: a novel PCR assay for methylation status of CpG islands. Proc Natl Acad Sci U S A. 1996;93:9821-9826.

(88) Hatada I, Fukasawa M, Kimura M et al. Genome-wide profiling of promoter methylation in human. Oncogene. 2006;25:3059-3064.

(89) Uchida T, Ohashi H, Aoki E et al. Clonality analysis by methylation-specific PCR for the human androgen-receptor gene (HUMARA-MSP). Leukemia. 2000;14:207-212.

(90) Massie CE, Mills IG. Chromatin immunoprecipitation (ChIP) methodology and readouts. Methods Mol Biol. 2009;505:123-137.

(91) Yoder SJ, Enkemann SA. ChIP-on-Chip Analysis methods for Affymetrix Tiling Arrays. Methods Mol Biol. 2009;523:367-381.

(92) Lockhart DJ, Dong H, Byrne MC et al. Expression monitoring by hybridization to high-density oligonucleotide arrays. Nat Biotechnol. 1996;14:1675-1680.

*(93) Schena M, Shalon D, Davis RW, Brown PO. Quantitative monitoring of gene expression patterns with a complementary DNA microarray. Science. 1995;270:467-470.

(94) Golub TR, Slonim DK, Tamayo P et al. Molecular classification of cancer: class discovery and class prediction by gene expression monitoring. Science. 1999;286:531-537. 
(95) Vardhanabhuti S, Blakemore SJ, Clark SM et al. A comparison of statistical tests for detecting differential expression using Affymetrix oligonucleotide microarrays. OMICS. 2006;10:555-566.

(96) Garzon R, Volinia S, Liu CG et al. MicroRNA signatures associated with cytogenetics and prognosis in acute myeloid leukemia. Blood. 2008;111:3183-3189.

(97) Johnson JM, Castle J, Garrett-Engele P et al. Genome-wide survey of human alternative premRNA splicing with exon junction microarrays. Science. 2003;302:2141-2144.

(98) Purdom E, Simpson KM, Robinson MD et al. FIRMA: a method for detection of alternative splicing from exon array data. Bioinformatics. 2008;24:1707-1714.

(99) O'Farrell PH. High resolution two-dimensional electrophoresis of proteins. J Biol Chem. 1975;250:4007-4021.

(100) Macek B, Mann M, Olsen JV. Global and site-specific quantitative phosphoproteomics: principles and applications. Annu Rev Pharmacol Toxicol. 2009;49:199-221.

(101) Jahn O, Hesse D, Reinelt M, Kratzin HD. Technical innovations for the automated identification of gel-separated proteins by MALDI-TOF mass spectrometry. Anal Bioanal Chem. 2006;386:92103.

(102) Shadforth I, Bessant C. Genome annotating proteomics pipelines: available tools. Expert Rev Proteomics. 2006;3:621-629.

(103) Favre-Kontula L, Sattonnet-Roche P, Magnenat E et al. Detection and identification of plasma proteins that bind GlialCAM using ProteinChip arrays, SELDI-TOF MS, and nano-LC MS/MS. Proteomics. 2008;8:378-388.

(104) Downard KM. lons of the interactome: the role of MS in the study of protein interactions in proteomics and structural biology. Proteomics. 2006;6:5374-5384.

(105) Irizarry RA, Hobbs B, Collin F et al. Exploration, normalization, and summaries of high density oligonucleotide array probe level data. Biostatistics. 2003;4:249-64.

(106) Xu XL, Olson JM, Zhao LP. A regression-based method to identify differentially expressed genes in microarray time course studies and its application in an inducible Huntington's disease transgenic model. Hum Mol Genet. 2002;11:1977-85.

(107) Forsberg EC, Bhattacharya D, Weissman IL. Hematopoietic stem cells: expression profiling and beyond. Stem Cell Rev. 2006;2:23-30.

(108) Rossi DJ, Jamieson CH, Weissman IL. Stems cells and the pathways to aging and cancer. Cell. 2008;132:681-696.

(109) Sharkis SJ, Collector MI, Barber JP, Vala MS, Jones RJ. Phenotypic and functional characterization of the hematopoietic stem cell. Stem Cells. 1997;15 Suppl 1:41-44. 
*(110) Ivanova NB, Dimos JT, Schaniel C et al. A stem cell molecular signature. Science. 2002;298:601604.

(111) Ramalho-Santos M, Yoon S, Matsuzaki Y, Mulligan RC, Melton DA. "Stemness": transcriptional profiling of embryonic and adult stem cells. Science. 2002;298:597-600.

(112) Evsikov AV, Solter D. Comment on " 'Stemness': transcriptional profiling of embryonic and adult stem cells" and "a stem cell molecular signature". Science. 2003;302:393.

(113) Fortunel NO, Otu HH, Ng HH et al. Comment on " 'Stemness': transcriptional profiling of embryonic and adult stem cells" and "a stem cell molecular signature". Science. 2003;302:393.

(114) Ivanova NB, Dimos JT, Schaniel C et al. Response to Comments on " 'Stemness': Transcriptional Profiling of Embryonic and Adult Stem Cells" and "A Stem Cell Molecular Signature". Science. 2003;302:393d.

(115) Forsberg EC, Prohaska SS, Katzman S et al. Differential expression of novel potential regulators in hematopoietic stem cells. PLoS Genet. 2005;1:e28.

(116) Blobel GA. CREB-binding protein and p300: molecular integrators of hematopoietic transcription. Blood. 2000;95:745-755.

(117) Eckner R. p300 and CBP as transcriptional regulators and targets of oncogenic events. Biol Chem. 1996;377:685-688.

(118) Kasper LH, Boussouar F, Ney PA et al. A transcription-factor-binding surface of coactivator p300 is required for haematopoiesis. Nature. 2002;419:738-43.

(119) Kung AL, Rebel VI, Bronson RT et al. Gene dose-dependent control of hematopoiesis and hematologic tumor suppression by CBP. Genes Dev. 2000;14:272-277.

(120) Rebel VI, Kung AL, Tanner EA et al. Distinct roles for CREB-binding protein and p300 in hematopoietic stem cell self-renewal. Proc Natl Acad Sci U S A. 2002;99:14789-94.

(121) Zhang P, Zhang X, Iwama A et al. PU.1 inhibits GATA-1 function and erythroid differentiation by blocking GATA-1 DNA binding. Blood. 2000;96:2641-2648.

(122) Zhang P, Behre G, Pan J et al. Negative cross-talk between hematopoietic regulators: GATA proteins repress PU.1. Proc Natl Acad Sci U S A. 1999;96:8705-8710.

(123) Weisel KC, Yildirim S, Schweikle E, Kanz L, Mohle R. Regulation of FLT3 and its ligand in normal hematopoietic progenitor cells. Ann Hematol. 2009;88:203-11.

(124) Majka M, Janowska-Wieczorek A, Ratajczak J et al. Numerous growth factors, cytokines, and chemokines are secreted by human CD34(+) cells, myeloblasts, erythroblasts, and megakaryoblasts and regulate normal hematopoiesis in an autocrine/paracrine manner. Blood. 2001;97:3075-85. 
(125) Amenomori T, Tomonaga M, Jinnai I et al. Cytogenetic and cytochemical studies on progenitor cells of primary acquired sideroblastic anemia (PASA): involvement of multipotent myeloid stem cells in PASA clone and mosaicism with normal clone. Blood. 1987;70:1367-1372.

(126) Linton PJ, Dorshkind K. Age-related changes in lymphocyte development and function. Nat Immunol. 2004;5:133-139.

(127) Clot J, Charmasson E, Brochier J. Age-dependent changes of human blood lymphocyte subpopulations. Clin Exp Immunol. 1978;32:346-351.

(128) Hong MS, Dan JM, Choi JY, Kang I. Age-associated changes in the frequency of naive, memory and effector CD8+ T cells. Mech Ageing Dev. 2004;125:615-618.

(129) Lucivero G, Surico G, Mazzini G, Dell'Osso A, Bonomo L. Age-related changes in the proliferative kinetics of phytohemagglutinin-stimulated lymphocytes. Analysis by uptake of tritiated precursors of DNA, RNA and proteins, and by flow cytometry. Mech Ageing Dev. 1988;43:259267.

(130) Chatta GS, Andrews RG, Rodger E et al. Hematopoietic progenitors and aging: alterations in granulocytic precursors and responsiveness to recombinant human G-CSF, GM-CSF, and IL-3. J Gerontol. 1993;48:M207-M212.

(131) NCl. SEER Cancer Statistics Review 1975-2003. 2004. 2004. National Cancer Institute. 1-31-2007. Ref Type: Electronic Citation

*(132) Nijnik A, Woodbine L, Marchetti C et al. DNA repair is limiting for haematopoietic stem cells during ageing. Nature. 2007;447:686-690.

(133) Janzen V, Forkert R, Fleming HE et al. Stem-cell ageing modified by the cyclin-dependent kinase inhibitor p16INK4a. Nature. 2006;443:421-426.

(134) Liang Y, Van Zant G, Szilvassy SJ. Effects of aging on the homing and engraftment of murine hematopoietic stem and progenitor cells. Blood. 2005;106:1479-1487.

(135) Chambers SM, Shaw CA, Gatza C et al. Aging hematopoietic stem cells decline in function and exhibit epigenetic dysregulation. PLoS Biol. 2007;5:e201.

(136) Kelly LM, Liu Q, Kutok JL et al. FLT3 internal tandem duplication mutations associated with human acute myeloid leukemias induce myeloproliferative disease in a murine bone marrow transplant model. Blood. 2002;99:310-318.

(137) Kelly LM, Kutok JL, Williams IR et al. PML/RARalpha and FLT3-ITD induce an APL-like disease in a mouse model. Proc Natl Acad Sci U S A. 2002;99:8283-8288.

(138) Huntly BJ, Gilliland DG. Leukaemia stem cells and the evolution of cancer-stem-cell research. Nat Rev Cancer. 2005;5:311-321.

(139) Bos JL, Fearon ER, Hamilton SR et al. Prevalence of ras gene mutations in human colorectal cancers. Nature. 1987;327:293-297. 
(140) Yu CE, Oshima J, Fu YH et al. Positional cloning of the Werner's syndrome gene. Science. 1996;272:258-262.

(141) Pennisi E. Premature aging gene discovered. Science. 1996;272:193-194.

(142) Kudlow BA, Kennedy BK, Monnat RJ, Jr. Werner and Hutchinson-Gilford progeria syndromes: mechanistic basis of human progeroid diseases. Nat Rev Mol Cell Biol. 2007;8:394-404.

(143) Matsumoto T, Shimamoto A, Goto M, Furuichi Y. Impaired nuclear localization of defective DNA helicases in Werner's syndrome. Nat Genet. 1997;16:335-336.

(144) Kyng KJ, May A, Kolvraa S, Bohr VA. Gene expression profiling in Werner syndrome closely resembles that of normal aging. Proc Natl Acad Sci U S A. 2003;100:12259-64.

(145) Castro E, Ogburn CE, Hunt KE et al. Polymorphisms at the Werner locus: I. Newly identified polymorphisms, ethnic variability of $1367 \mathrm{Cys} / \mathrm{Arg}$, and its stability in a population of Finnish centenarians. Am J Med Genet. 1999;82:399-403.

(146) Agrelo R, Cheng WH, Setien F et al. Epigenetic inactivation of the premature aging Werner syndrome gene in human cancer. Proc Natl Acad Sci U S A. 2006;103:8822-8827.

*(147) Stirewalt DL, Choi YE, Sharpless NE et al. Decreased IRF8 expression found in aging hematopoietic progenitor/stem cells. Leukemia. 2009;23:391-393.

(148) Holtschke T, Lohler J, Kanno Y et al. Immunodeficiency and chronic myelogenous leukemia-like syndrome in mice with a targeted mutation of the ICSBP gene. Cell. 1996;87:307-317.

(149) Schwieger M, Lohler J, Friel J et al. AML1-ETO inhibits maturation of multiple lymphohematopoietic lineages and induces myeloblast transformation in synergy with ICSBP deficiency. J Exp Med. 2002;196:1227-1240.

(150) Schmidt M, Hochhaus A, Nitsche A, Hehlmann R, Neubauer A. Expression of nuclear transcription factor interferon consensus sequence binding protein in chronic myeloid leukemia correlates with pretreatment risk features and cytogenetic response to interferon-alpha. Blood. 2001;97:3648-3650.

(151) Diaz-Blanco E, Bruns I, Neumann F et al. Molecular signature of CD34(+) hematopoietic stem and progenitor cells of patients with CML in chronic phase. Leukemia. 2007;21:494-504.

(152) Schmidt M, Nagel S, Proba J et al. Lack of interferon consensus sequence binding protein (ICSBP) transcripts in human myeloid leukemias. Blood. 1998;91:22-29.

(153) Serrano M, Hannon GJ, Beach D. A new regulatory motif in cell-cycle control causing specific inhibition of cyclin D/CDK4. Nature. 1993;366:704-707.

(154) Haidar MA, Cao XB, Manshouri T et al. p16INK4A and p15INK4B gene deletions in primary leukemias. Blood. 1995;86:311-315. 
(155) Sulong S, Moorman AV, Irving JA et al. A comprehensive analysis of the CDKN2A gene in childhood acute lymphoblastic leukemia reveals genomic deletion, copy number neutral loss of heterozygosity, and association with specific cytogenetic subgroups. Blood. 2009;113:100-107.

(156) Molofsky AV, Slutsky SG, Joseph NM et al. Increasing p16INK4a expression decreases forebrain progenitors and neurogenesis during ageing. Nature. 2006;443:448-452.

(157) Krishnamurthy J, Ramsey MR, Ligon KL et al. p16INK4a induces an age-dependent decline in islet regenerative potential. Nature. 2006;443:453-457.

(158) Stirewalt DL, Kopecky KJ, Meshinchi S et al. FLT3, RAS, and TP53 mutations in elderly patients with acute myeloid leukemia. Blood. 2001;97:3589-3595.

(159) Dumble M, Moore L, Chambers SM et al. The impact of altered p53 dosage on hematopoietic stem cell dynamics during aging. Blood. 2007;109:1736-1742.

(160) Sterkers Y, Preudhomme C, Lai JL et al. Acute myeloid leukemia and myelodysplastic syndromes following essential thrombocythemia treated with hydroxyurea: high proportion of cases with 17p deletion. Blood. 1998;91:616-622.

(161) Venkatachalam S, Shi YP, Jones SN et al. Retention of wild-type p53 in tumors from p53 heterozygous mice: reduction of p53 dosage can promote cancer formation. EMBO J. 1998;17:4657-4667.

(162) Tyner SD, Venkatachalam S, Choi J et al. p53 mutant mice that display early ageing-associated phenotypes. Nature. 2002;415:45-53.

(163) Bojesen SE, Nordestgaard BG. The common germline Arg72Pro polymorphism of p53 and increased longevity in humans. Cell Cycle. 2008;7:158-163.

(164) van Heemst D, Mooijaart SP, Beekman M et al. Variation in the human TP53 gene affects old age survival and cancer mortality. Exp Gerontol. 2005;40:11-15.

*(165) Sharpless NE, DePinho RA. How stem cells age and why this makes us grow old. Nat Rev Mol Cell Biol. 2007;8:703-713.

(166) Finkel T, Serrano M, Blasco MA. The common biology of cancer and ageing. Nature. 2007;448:767-774.

(167) Rossi DJ, Bryder D, Zahn JM et al. Cell intrinsic alterations underlie hematopoietic stem cell aging. Proc Natl Acad Sci U S A. 2005;102:9194-9199.

(168) Prall WC, Czibere A, Jager $M$ et al. Age-related transcription levels of KU70, MGST1 and BIK in CD34+ hematopoietic stem and progenitor cells. Mech Ageing Dev. 2007;128:503-510.

(169) Nilsson SK, Johnston HM, Coverdale JA. Spatial localization of transplanted hemopoietic stem cells: inferences for the localization of stem cell niches. Blood. 2001;97:2293-2299. 
(170) Adams GB, Chabner KT, Alley IR et al. Stem cell engraftment at the endosteal niche is specified by the calcium-sensing receptor. Nature. 2006;439:599-603.

(171) Ilnytskyy Y, Zemp FJ, Koturbash I, Kovalchuk O. Altered microRNA expression patterns in irradiated hematopoietic tissues suggest a sex-specific protective mechanism. Biochem Biophys Res Commun. 2008;377:41-5.

(172) Dressman HK, Muramoto GG, Chao NJ et al. Gene expression signatures that predict radiation exposure in mice and humans. PLoS Med. 2007;4:e106.

(173) Lu X, de la Pena L, Barker C, Camphausen K, Tofilon PJ. Radiation-induced changes in gene expression involve recruitment of existing messenger RNAs to and away from polysomes. Cancer Res. 2006;66:1052-61.

(174) Bender MA, Gooch PC. Persistent chromosome aberrations in irradiated human subjects. Radiat Res. 1962;16:44-53.

(175) Amundson SA, Grace MB, McLeland CB et al. Human in vivo radiation-induced biomarkers: gene expression changes in radiotherapy patients. Cancer Res. 2004;64:6368-71.

(176) Mori M, Benotmane MA, Vanhove $D$ et al. Effect of ionizing radiation on gene expression in $\mathrm{CD} 4+\mathrm{T}$ lymphocytes and in Jurkat cells: unraveling novel pathways in radiation response. Cell Mol Life Sci. 2004;61:1955-64.

(177) Ford JM. Regulation of DNA damage recognition and nucleotide excision repair: another role for p53. Mutat Res. 2005;577:195-202.

(178) Pukkala E, Auvinen A, Wahlberg G. Incidence of cancer among Finnish airline cabin attendants, 1967-92. BMJ. 1995;311:649-652.

(179) Nicholas JS, Butler GC, Davis S et al. Stable chromosome aberrations and ionizing radiation in airline pilots. Aviat Space Environ Med. 2003;74:953-956.

(180) Wang Z, Neuberg D, Su L et al. Prospective study of metal fume-induced responses of global gene expression profiling in whole blood. Inhal Toxicol. 2008;20:1233-44.

(181) Schmidt WM, Spiel AO, Jilma B, Wolzt M, Muller M. In vivo profile of the human leukocyte microRNA response to endotoxemia. Biochem Biophys Res Commun. 2009;380:437-41.

(182) Suzuki T, Hashimoto S, Toyoda N et al. Comprehensive gene expression profile of LPS-stimulated human monocytes by SAGE. Blood. 2000;96:2584-91.

(183) Lampe JW, Stepaniants SB, Mao M et al. Signatures of environmental exposures using peripheral leukocyte gene expression: tobacco smoke. Cancer Epidemiol Biomarkers Prev. 2004;13:445-53.

*(184) van Leeuwen DM, van Agen E, Gottschalk RW et al. Cigarette smoke-induced differential gene expression in blood cells from monozygotic twin pairs. Carcinogenesis. 2007;28:691-7. 
(185) Bijl M, Horst G, Limburg PC, Kallenberg CG. Effects of smoking on activation markers, Fas expression and apoptosis of peripheral blood lymphocytes. Eur J Clin Invest. 2001;31:550-3.

(186) van Eeden SF, Hogg JC. The response of human bone marrow to chronic cigarette smoking. Eur Respir J. 2000;15:915-21.

(187) Vijayalaxmi, Evans HJ. In vivo and in vitro effects of cigarette smoke on chromosomal damage and sister-chromatid exchange in human peripheral blood lymphocytes. Mutat Res.

1982;92:321-32.

(188) Bridges RB, Wyatt RJ, Rehm SR. Effects of smoking on inflammatory mediators and their relationship to pulmonary dysfunction. Eur J Respir Dis Suppl. 1986;146:145-52.

(189) Kaufman DW, Kelly JP, Rosenberg L, Anderson TE, Mitchell AA. Recent patterns of medication use in the ambulatory adult population of the United States: the Slone survey. JAMA. 2002;287:337-44.

(190) Vogel M, Pfeifer S, Schaub RT et al. Decreased levels of dopamine D3 receptor mRNA in schizophrenic and bipolar patients. Neuropsychobiology. 2004;50:305-10.

(191) Iga J, Ueno S, Yamauchi K et al. Serotonin transporter mRNA expression in peripheral leukocytes of patients with major depression before and after treatment with paroxetine. Neurosci Lett. 2005;389:12-6.

(192) Westermark B, Claesson-Welsh L, Heldin CH. Structural and functional aspects of plateletderived growth factor and its receptors. Ciba Found Symp. 1990;150:6-14.

(193) Bazan JF. Structural design and molecular evolution of a cytokine receptor superfamily. Proc Natl Acad Sci U S A. 1990;87:6934-6938.

(194) Cannistra SA, Groshek P, Garlick R, Miller J, Griffin JD. Regulation of surface expression of the granulocyte/macrophage colony-stimulating factor receptor in normal human myeloid cells. Proc Natl Acad Sci U S A. 1990;87:93-97.

(195) Chiba S, Tojo A, Kitamura T et al. Characterization and molecular features of the cell surface receptor for human granulocyte-macrophage colony-stimulating factor. Leukemia. 1990;4:2936.

(196) Bierie B, Moses HL. Tumour microenvironment: TGFbeta: the molecular Jekyll and Hyde of cancer. Nat Rev Cancer. 2006;6:506-20.

(197) Rizzo P, Osipo C, Foreman K et al. Rational targeting of Notch signaling in cancer. Oncogene. 2008;27:5124-5131.

(198) Reya T, Clevers H. Wnt signalling in stem cells and cancer. Nature. 2005;434:843-850.

(199) Nusse R. Wnt signaling and stem cell control. Cell Res. 2008;18:523-527. 
(200) Huang HC, Klein PS. The Frizzled family: receptors for multiple signal transduction pathways. Genome Biol. 2004;5:234.

(201) Bilic J, Huang YL, Davidson G et al. Wnt induces LRP6 signalosomes and promotes dishevelleddependent LRP6 phosphorylation. Science. 2007;316:1619-1622. 